\title{
Wieloaspektowa rola glukozy i jej metabolizmu w regulacji parametrów fizjologicznych i potencjału reprodukcyjnego komórek na podstawie badań z użyciem drożdży Saccharomyces cerevisiae
}

\section{STRESZCZENIE}

$G$ lukoza jest nie tylko podstawowym źródłem energii, ale także związkiem odgrywającym istotną rolę $w$ metabolizmie i utrzymaniu prawidłowego stanu fizjologicznego komórki. Jest to szczególnie widoczne w przypadku drożdży, u których wpływ glukozy na stan fizjologiczny komórki ma bezpośredni charakter objawiający się m.in. uzyskiwaniem energii na drodze fermentacji bądź oddychania tlenowego w zależności od dostępności glukozy w środowisku. Zależna od glukozy modulacja wewnątrzkomórkowych szlaków metabolicznych rzutuje na potencjał reprodukcyjny i długość życia komórek, co ściśle wiąże glukozę z badaniami dotyczącymi restrykcji kalorycznej. Jednocześnie, zauważalny jest brak danych dotyczących sytuacji nadmiaru kalorii i jej konsekwencji na poziomie komórkowym. Wykorzystując jako model badawczy komórki drożdży Saccharomyces cerevisiae stwierdzono istotną zależność między stężeniem glukozy, możliwościami biosyntetycznymi a potencjałem reprodukcyjnym i całkowitą długością życia komórek drożdży. Wysokie stężenia glukozy odpowiadające warunkom nadmiaru kalorii prowadzą $w$ ich przypadku do zwiększenia poziomu reaktywnych form tlenu, wzrostu wielkości i biomasy komórki, ale jednocześnie do obniżenia możliwości reprodukcyjnych i skrócenia całkowitej długości życia komórki. Zaobserwowany negatywny wpływ nadmiaru glukozy na parametry fizjologiczne komórki oraz złożoność i wzajemne powiązania wewnątrzkomórkowych szlaków metabolicznych sugerują potrzebę dalszych analiz metabolizmu glukozy.

\section{WPROWADZENIE}

Metabolizm glukozy jest zagadnieniem, które od lat jest przedmiotem zainteresowania biochemików, co potwierdzają odkrycia Pasteura, Büchnerów czy badania Embdena, Meyerhoffa i Parnasa. Mimo, iż wewnątrzkomórkowe drogi przekształcania glukozy są dobrze scharakteryzowane, to biorąc pod uwagę, że stanowią one skomplikowaną sieć metaboliczną nadal niezwykle istotne jest dostarczanie nowych informacji na temat możliwych powiązań pomiędzy poszczególnymi szlakami metabolicznymi oraz tego w jaki sposób komórka moduluje aktywność tych szlaków w odpowiedzi na zmiany w otaczającym ją środowisku. Szczególnie ważne wydaje się to w kontekście swoistego paradoksu metabolicznego polegającego na wykorzystywaniu przez intensywnie proliferujące komórki mniej efektywnego, pod względem liczby wytworzonych cząsteczek ATP, procesu tj. fermentacji/glikolizy w warunkach tlenowych. Zjawisko to, niewątpliwie związane z komórkami drożdży S. cerevisiae i określane mianem efektu Crabtree [1] obserwuje się także w przypadku komórek nowotworowych (efekt Warburga) [2,3] jak też komórek macierzystych [4,5]. Współczesne koncepcje wyjaśniające podłoże tego zjawiska wskazują, że może to być związane ze specyficzną wydajnością energetyczną rozumianą jako bilans zysków energetycznych oraz kosztów inwestycji jakie musi ponieść komórka w przypadku danego sposobu uzyskiwania energii [6,7]. Niemniej jednak zagadnienie to wymaga dalszych analiz, a badania prowadzone w oparciu o komórki drożdży, mogą okazać się bardzo przydatne dla wyjaśnienia jego złożonego charakteru.

\section{POBIERANIE I WYKORZYSTANIE GLUKOZY PRZEZ KOMÓRKĘ}

Procesy życiowe komórek wymagają stałego dopływu energii, którą pozyskują z dostępnych w otoczeniu substratów energetycznych. Glukozę uważa się za podstawowy substrat energetyczny bowiem wewnątrzkomórkowe procesy metaboliczne bazują na związkach będących jej pochodnymi. Glukoza zapewnia także szkielet węglowy wykorzystywany w komórkowych procesach biosyntetycznych. Jej przemiany w procesie glikolizy, poszczególnych reakcjach cyklu Krebsa oraz szlaku pentozofosforanowym (szlak PPP - ang. pentose phosphate pathway) dostarczają metabolitów węglowych niezbędnych do biosyntezy kluczowych składników komórki, w tym nukleotydów, aminokwasów, lipidów i witamin $[2,4,8]$. Powoduje to niezwykłą wrażliwość komórek na zmiany stężenia glukozy w swoim otoczeniu, o czym świadczy obecność w komórce szeregu białek spełniających rolę sensorów glukozy, białek związanych z wewnątrzko-

\section{Roman Maślanka ${ }^{\unrhd}$, \\ Renata Zadrąg-Tęcza}

Zakład Biochemii i Biologii Komórki, Kolegium Nauk Przyrodniczych, Uniwersytet Rzeszowski, Rzeszów

https://doi.org/10.18388/pb.2021_369

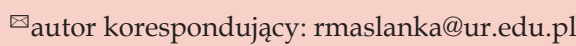

Słowa kluczowe: glukoza, restrykcja kaloryczna, nadmiar kalorii, wielkość komórki, możliwości biosyntetyczne, potencjał reprodukcyjny komórki, drożdże Saccharomyces cerevisiae

Wykaz skrótów: szlak PPP (ang. pentose phosphate pathway) - szlak pentozofosforanowy; CR (ang. calorie restriction) - restrykcja kaloryczna; CE (ang. calorie excess) - nadmiar kalorii; $\mathrm{NADP}(\mathrm{H})$ (ang. Nicotinamide adenine dinucleotide phosphate) - fosforan dinukleotydu nikotynoamidoadeninowego; pula formy zredukowanej (NADPH) i utlenionej $\left(\mathrm{NADP}^{+}\right.$); rDNA (ang. ribosomal DNA) - rybosomalny DNA; HXT (ang. hexose transporters) - transportery heksoz występujące w komórkach drożdży; GLUT (ang. glucose transporters) - transportery glukozy występujące w komórkach ludzkich; RFT - reaktywne formy tlenu; szlak cAMP/PKA (ang. cyclic AMP/protein kinase A pathway) - wewnątrzkomórkowy szlak sygnalizacyjny zależny od cyklicznego AMP i aktywności białkowej kinazy A

\section{ARTYKUŁ OPUBLIKOWANY}

W RAMACH

Nagrody Polskiego

Towarzystwa Biochemicznego

i firmy Merck Sp. z o.o.

za najlepszą pracę doktorską z

biochemii

im. Witolda Drabikowskiego

\section{Laureat: dr Roman Maślanka}

TYTUŁ ROZPRAWY: Wpływ

glukozy i jej metabolizmu na stan fizjologiczny, potencjał reprodukcyjny i długość życia komórek drożdży Saccharomyces cerevisiae

Promotor: dr hab. Renata Zadrąg-Tęcza 
mórkową sygnalizacją uwarunkowaną obecnością glukozy oraz błonowych transporterów glukozy [9,10].

Transportery glukozy, stanowią rodzinę białek, które w wyniku niewielkich zmian w łańcuchu polipeptydowym (m.in. poprzez zmiany miejsca glikozylacji) znacząco różnią się stopniem powinowactwa do glukozy $\left(K_{\mathrm{m}}\right.$ od 1 do ok. 20 $\mathrm{mM}$ dla transporterów z rodziny GLUT występujących w komórkach ludzkich; $K_{\mathrm{m}}$ od 1 do $100 \mathrm{mM}$ dla transporterów z rodziny HXT występujących w komórkach drożdży Saccharomyces cerevisiae) [9,11]. Ponadto są one białkami stosunkowo konserwatywnymi ewolucyjnie, przez co wykazują szereg podobieństw w szerokim zakresie gatunków, charakteryzując się jednocześnie pewnymi różnicami gatunkowymi i tkankowymi. W przypadku komórek drożdży jest to m.in. możliwość szybkiej wymiany jednej izoformy transportera HXT na inną w odpowiedzi na zmianę poziomu glukozy czy też obecność innych cukrów w środowisku. Z kolei w przypadku komórek ludzkich transportery GLUT wykazują specyficzność tkankową, odpowiadającą określonemu zapotrzebowaniu na glukozę [9,11]. Przykładowo, transporter GLUT3 o wysokim powinowactwie do glukozy $\left(K_{\mathrm{m}}\right.$ ok. $\left.1 \mathrm{mM}\right)$ jest specyficzny dla komórek układu nerwowego. Wynika to nie tylko z ciągłego i wysokiego zapotrzebowania energetycznego komórek nerwowych, ale także ze względu na fakt, iż dla tego typu komórek glukoza stanowi podstawowy substrat energetyczny $[9,12]$. Co więcej, wysoka wydajność transportu glukozy przy udziale tego transportera tłumaczy jego obecność także w komórkach embrionalnych i komórkach tworzących łożysko [12]. Istotnym odbiorcą i rezerwuarem dostępnej puli glukozy w organizmie człowieka są komórki mięśni szkieletowych oraz adipocyty, które wychwytują glukozę dzięki obecności transporterów GLUT4. Specyfiką tego typu transporterów jest uzależnienie ich aktywności od poziomu insuliny, co powoduje że zarówno komórki mięśni szkieletowych jak i komórki tkanki tłuszczowej sprawnie reagują na zmiany stężenia glukozy w organizmie. Z kolei inny rodzaj transporterów, GLUT2 wyróżniający się dużą wartością Km dla glukozy (17-20 mM) występuje w komórkach wątroby oraz komórkach $\beta$-trzustki, co powoduje pobieranie glukozy przez te komórki tylko wtedy gdy jej stężenie w otoczeniu jest duże. To z kolei wpływa na aktywność procesu glikogenogenezy/glikogenolizy oraz sekrecję insuliny, odgrywających kluczową rolę w utrzymaniu homeostazy glukozy [9].

\section{HOMEOSTAZA GLUKOZY W ORGANIZMIE CZŁOWIEKA}

Biorąc pod uwagę zaangażowanie glukozy w szereg procesów wewnątrzkomórkowych, utrzymanie jej optymalnego poziomu wymaga szeregu mechanizmów regulacyjnych, odpowiadających zarówno za obniżanie jak i podwyższanie tego poziomu we krwi (Ryc. 1). Stąd utrzymanie homeostazy glu-
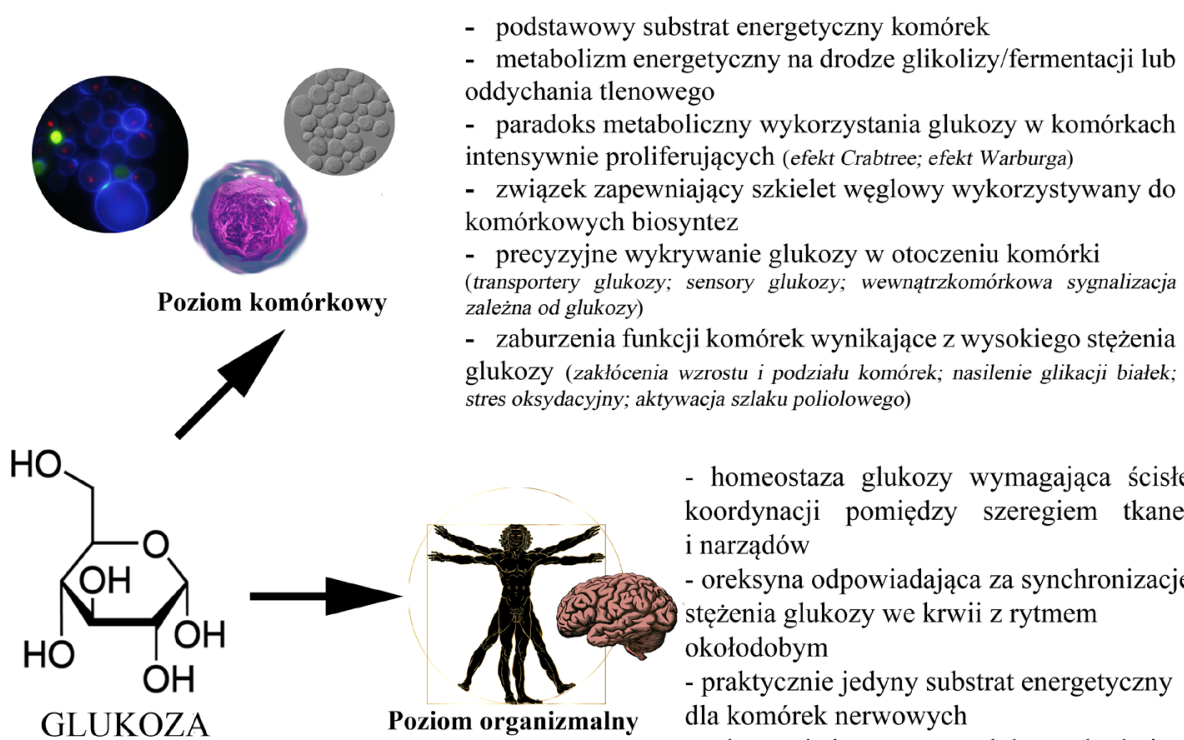

- homeostaza glukozy wymagająca ścisłej koordynacji pomiędzy szeregiem tkanek i narząów

- oreksyna odpowiadająca za synchronizację stężenia glukozy we krwii z rytmem okołodobym - praktycznie jedyny substrat energetyczny dla komórek nerwowych

- zaburzenia homeostazy glukozy skutkujące hiperglikemią, insulinoopornością, hiperinsulinemią i hipoinsulinemią doprowadzające do rozwoju chorób metabolicznych w tym cukrzycy typu 2 i otyłości

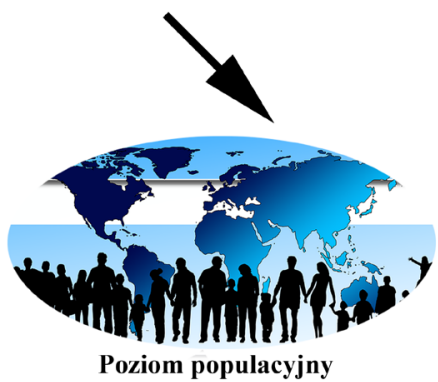

- dane epidemiologiczne wskazujące na skalę problemu cukrzycy (463 mln osób w 2019 r., $700 \mathrm{mln}$ - szacunkowa liczba osób z cukrzycą w 2045 r.) - społeczne uwarunkowania rozwoju cukrzycy typu 2 (problemy ze snem wynikajace $z$ dłuższej aktywności dobowej i zanieczyszczenia świetlnego, ilość substancji energetycznych dostarczanych do organizmu) - stan nadmiaru kalorii jako nie występujące naturalnie w środowisku wyzwanie dla organizmu współczesnego człowieka - pozytywne skutki wynikające z restrykcji kalorycznej i okresowego głodzenia

Rycina 1. Znaczenie glukozy dla komórki, organizmu oraz konsekwencje wynikające z zaburzeń homeostazy glukozy. 
kozy wymaga zarówno komunikacji, jak i współdziałania poszczególnych tkanek i narządów, ze szczególnym uwzględnieniem mózgu, wątroby, trzustki, mięśni szkieletowych i adipocytów budujących tkankę tłuszczową. Istotną rolę w tej komunikacji odgrywają cząsteczki sygnałowe takie jak insulina, adiponektyna i lektyna, a także sama glukoza oraz jej metabolity $[13,14]$. Ponadto homeostaza glukozy w organizmie człowieka zależy także od działania zegara biologicznego synchronizującego metabolizm glukozy względem aktualnej pory dnia. Ośrodek utożsamiany z zegarem biologicznym znajduje się w obszarze podwzgórza tuż nad skrzyżowaniem nerwów wzrokowych, przez co umożliwia skoordynowanie metabolizmu z sygnałami informującymi o ilości światła docierającymi z siatkówki. Działalność zegara biologicznego odpowiada m.in. za występowanie cyklicznych, dobowych wahań stężenia glukozy we krwi, w tym występowanie charakterystycznego dla godzin porannych wysokiego stężenia glukozy, któremu nie towarzyszy zwiększenie wydzielania insuliny, co powszechnie nazywane jest „fenomenem świtu”. Przyjmuje się, że za utrzymanie związku pomiędzy rytmem okołodobowym a stężeniem glukozy we krwi odpowiada oreksyna. Neuropeptyd ten pobudza neurony układu współczulnego, przez co m.in. zwiększa syntezę glukozy w wątrobie oraz jej pobieranie przez mięśnie. Istnienie takowego zegara biologicznego ma istotny sens ewolucyjny ponieważ umożliwia wzajemną relację między dostępnością światła, aktywnością fizyczną i pobieraniem pokarmu. Jednakże, w odniesieniu do obecnego stylu życia i odżywiania, dłuższej aktywności dobowej ludzi oraz coraz powszechniejszego zjawiska tzw. „zanieczyszczenia świetlnego" funkcjonowanie zegara biologicznego jest mocno zakłócone, co w konsekwencji doprowadza do zaburzenia wielu procesów metabolicznych, w tym także utrzymania homeostazy glukozy $[15,16]$.

\section{PRZYCZYNY I SKUTKI ZABURZENIA HOMEOSTAZY GLUKOZY}

Zaburzenia homeostazy glukozy wynikają z nieprawidłowej gospodarki energetycznej organizmu, co najczęściej prowadzi do stanu hiperglikemii czyli wzrostu stężenia glukozy we krwi. Stan utrzymującego się wysokiego stężenia glukozy prowadzi z kolei do uszkodzenia i niewydolności wielu narządów jako efekt zaburzenia funkcji poszczególnych komórek. Zaobserwowano, że narażenie komórek na wysokie stężenia glukozy może powodować m.in.: i) zakłócenia regulacji wzrostu i podziałów komórek w następstwie zmiany ich wielkości, kształtu i wakuolaryzacji [17,18]; ii) nasilenie zjawiska glikacji białek o długim okresie półtrwania i powstawanie końcowych produktów glikacji (AGEs) niewrażliwych na degradację proteolityczną [19]; iii) indukcję stresu oksydacyjnego $\mathrm{w}$ następstwie zwiększonej generacji reaktywnych form tlenu (RFT) i/lub obniżenia komórkowej puli NADPH $[20,21]$; czy iv) nasiloną aktywację szlaku poliolowego skutkującą wewnątrzkomórkowym gromadzeniem sorbitolu i fruktozy, których odkładanie w aksonach komórek nerwowych może doprowadzić do ich demielinizacji i rozwoju neuropatii [22]. O tym jak kluczowa dla organizmu człowieka jest ścisła kontrola poziomu glukozy, świadczy stale zwiększający się odsetek osób dotkniętych nadwagą i otyłością oraz towarzyszącymi im zaburzeniami metabolicznymi w tym cukrzycą typu 2 [13]. Według danych epidemiologicznych problem cukrzycy (zwłaszcza typu 2) jest niezwykle powszechny, bowiem na chwilę obecną dotyczy on ponad $463 \mathrm{mln}$ osób na świecie, a szacunkowe dane prognostyczne wskazują, że w ciągu najbliższych 15 lat liczba ta wzrośnie do $700 \mathrm{mln}$ [23]. Fundamentalną przyczyną rozwoju cukrzycy typu 2 jest zaburzenie mechanizmu działania insuliny, której wpływ na utrzymanie prawidłowego poziomu glukozy we krwi odbywa się głównie poprzez zwiększenie transportu glukozy do wnętrza komórek przy jednoczesnym hamowaniu procesów rozpadu glikogenu i kwasów tłuszczowych. Jednakże, w przypadku cukrzycy typu 2, aktywność insuliny nie skutkuje obniżaniem stężenia glukozy we krwi. Przyczyną tego zaburzenia jest insulinooporność objawiająca się obniżoną wrażliwością komórek na działanie insuliny i pobieraniem przez nie zbyt małej ilości glukozy z krwi. Powoduje to przedłużające się stany hiperglikemii, co z kolei zmusza organizm do zwiększonej produkcji insuliny (hiperinsulinemia). Efekt tego działania jest krótkotrwały, bowiem w dłuższej perspektywie prowadzi do odkładania tłuszczu w adipocytach i komórkach wątroby, a stale zwiększona produkcja insuliny prowadzi do przeeksploatowania komórek trzustki, co w rezultacie skutkuje hipoinsulinemią (bardzo niskim stężeniem insuliny we krwi) [24].

Do istotnych czynników związanych z rozwojem cukrzycy typu 2 należą: czynniki genetyczne, brak snu zaburzający działanie zegara biologicznego, postępujące wraz z wiekiem upośledzenie tolerancji glukozy, ale także jakość i ilość składników pokarmowych dostarczanych do organizmu. Przez stulecia panowało powszechne przekonanie, że obfite posiłki stanowią synonim bogactwa i zdrowia. Aczkolwiek przez większość dziejów codzienne przejadanie się było ograniczone tylko do uprzywilejowanych grup społecznych. Dopiero współczesny, wybitnie konsumpcyjny, tryb życia społeczeństw krajów wysokorozwiniętych przyczynił się do upowszechnienia zjawiska dostarczania organizmowi nadmiernej, i nie wynikającej z rzeczywistego zapotrzebowania, liczby kalorii. Nadmiar ten stał się nowym wyzwaniem dla organizmu człowieka, bowiem jego dotychczasowa ewolucja odbywała się w środowisku, w którym dostępność pożywienia była głównie okresowa. Okresowość ta doprowadziła do wytworzenia szeregu adaptacji pozwalających na funkcjonowanie organizmu w czasie braku dostępu do pożywienia i ukształtowania łowiecko-zbierackiego genotypu człowieka $[25,26]$.

\section{OGRANICZENIE I NADMIAR KALORII}

Wieloletnie obserwacje i prowadzone badania potwierdzają ogromny wpływ diety na jakość i długość życia człowieka. Wskazują na to również badania prowadzone w oparciu o organizmy modelowe, a najbardziej znanymi w tym zakresie są te dotyczące zagadnienia restrykcji kalorycznej (CR - ang. calorie restriction). Restrykcja kaloryczna oznacza ograniczenie podaży składników odżywczych, w tym także glukozy i innych cukrów prostych, a jej głównym założeniem jest obniżenie liczby przyjmowanych kalorii (średnio o ok. 30\% w stosunku do zapotrzebowania organizmu) przy jednoczesnej dostępności wszystkich składników pokarmowych $[27,28]$. W licznych badaniach wykazano, że CR przeciwdziała rozwojowi chorób zależnych od wieku, w tym chorób sercowo-naczyniowych, nowotworów czy zaburzeń neurologicznych, poprawia homeostazę glukozy a także wrażliwość na insulinę [29,30]. Poza tym usprawnia mechanizmy naprawy DNA oraz zapobiega 
gromadzeniu uszkodzonych białek na terenie komórki [31,32]. Pozytywne skutki wynikające z ograniczenia kalorii tłumaczone są przez szereg hipotez wskazujących między innymi na: obniżenie tempa metabolizmu, redukcję poziomu generowanych RFT, poprawę wewnątrzkomórkowych mechanizmów kontroli jakości i ilości białek, zmiany związane z aktywnością sirtuin i stanem redoks komórki czy działanie na zasadzie hormezy [30,32,33]. Poszczególne hipotezy traktowane indywidualnie nie wyjaśniają w pełni całego zjawiska, co sugeruje jego kompleksowy charakter oraz możliwość addytywnego działania poszczególnych mechanizmów [32,34]. Mimo licznych pozytywnych efektów wynikających z zastosowania restrykcji kalorycznej, stanowi ona poważne wyzwanie ze względu na konieczność wyliczania dziennego limitu spożywanych kalorii oraz brak dowolności w spożywaniu posiłków. Stąd alternatywną metodą wobec restrykcji kalorycznej, odnoszącą równie pozytywne rezultaty, jest okresowe głodzenie (IF ang. intermittent fasting). W skrócie polega ono na naprzemiennych okresach spożywania normalnej i znacznie obniżonej liczby kalorii [29]. Wartym podkreślenia jest fakt, że zjawisko okresowego głodzenia ma istotne umocowanie historyczne, bowiem można łączyć go zarówno ze zbieracko-łowieckim trybem życia ludzi pierwotnych jak też licznymi nakazami postów religijnych.

Choć pozytywny wpływ CR na poprawę sprawności fizjologicznej organizmów wydaje się być niekwestionowany $[28,35,36]$, to jej wpływ na długość życia organizmów i mechanizm działania wydają się być sprawami mniej oczywistymi i stanowiącymi przedmiot żywej dyskucji naukowej [26,35,37-39]. Szczególnie istotne w tej materii okazały się badania prowadzone na małpach $\mathrm{z}$ rodzaju Rhesus $[37,39]$. Zaobserwowano bowiem, że dostarczanie składników odżywczych na zasadzie ad libitum (nieograniczonego dostępu do pokarmu) może być rozpatrywane jako stan nadmiaru kalorii (CE - ang. calorie excess), w którym ilość dostarczanych składników odżywczych przewyższa rzeczywiste zapotrzebowanie energetyczne organizmu [26,38]. Co więcej, stan taki praktycznie nie występuje naturalnie w przyrodzie, gdzie dostępność składników odżywczych jest ograniczona. Jednocześnie konsekwencje przedłużającego się stanu nadmiaru kalorii nie są w pełni poznane, przy czym szczególnie mało danych można znaleźć w odniesieniu do konsekwencji obserwowanych na poziomie komórkowym.

\section{DROŻDŻE JAKO KOMÓRKOWY MODEL W ANALIZACH RESTRYKCJI KALORYCZNEJ I METABOLIZMU GLUKOZY}

W badaniach analizujących wpływ CR na funkcjonowanie komórki jako jeden z modeli badawczych wykorzystuje się komórki drożdży S. cerevisiae, dla których warunki restrykcji kalorycznej uzyskuje się poprzez obniżenie zawartości glukozy w podłożu z 2\% używanych standardowo do poziomu 0,5\% lub niżej. Badania z wykorzystaniem drożdży koncentrują się głównie na analizie wpływu warunków CR na replikacyjną długość życia (długość życia określaną na podstawie liczby komórek potomnych wytworzonych przez pojedynczą komórkę „matkę”) i sprawność fizjologiczną komórek. Wyniki prowadzonych badań nie dają jednak jednoznacznych konkluzji [40-47]. Dlatego też kwestia ta jest nadal przedmiotem wielu badań. Z kolei niewiele badań prowadzonych jest w warunkach przeciwnych do restrykcji kalorycznej, czyli w warunkach nadmiaru kalorii (CE), wynikających z wysokich stężeń glukozy $[47,48]$. Obecnie istnieją tylko ograniczone dane pokazujące wpływ wysokiego stężenia glukozy na wybrane aspekty fizjologii komórek drożdży [43,49].

Zastosowanie komórek drożdży jako modelu badawczego w analizach dotyczących metabolizmu glukozy ma kilka istotnych atutów w tym: (i) podobieństwo szlaków metabolizowania glukozy oraz szlaków biosyntetycznych wykorzystujących metabolity glukozy jako źródło szkieletu węglowego w komórkach drożdży oraz w komórkach wyższych eukariontów; (ii) krótki cykl życiowy, małe rozmiary oraz możliwość prowadzenia szerokiego zakresu manipulacji genetycznych; (iii) ścisły związek między typem metabolizmu energetycznego a dostępnością glukozy. Związek miedzy typem metabolizmu energetycznego a dostępnością glukozy jest na tyle silny, że to właśnie obecność glukozy, a nie dostępność tlenu determinuje w komórkach drożdży sposób uzyskiwania energii na drodze fermentacji bądź oddychania tlenowego. Może to mieć istotne znaczenie dla porównywania metabolizmu komórek drożdży z metabolizmem komórek nowotworowych czy komórek macierzystych. Specyficzna reakcja komórek drożdży wywoływana dostępnością glukozy wynika z faktu, iż pojedyncza komórka drożdży jest jednocześnie odrębnym organizmem, przez co działanie glukozy w ich przypadku jest jeszcze bardziej bezpośrednie. Powoduje to jednocześnie konieczność istnienia dodatkowych mechanizmów monitorujących poziom glukozy w środowisku, przez co umożliwiających szybką odpowiedź na częste zmiany jej dostępności [11]. Stąd, komórki drożdży oprócz transporterów glukozy posiadają także szereg białek błonowych spełniających rolę sensorów stężenia glukozy. Należą do nich m.in. białka Snf3 i Rgt2, wykrywające odpowiednio niskie i wysokie stężenia glukozy, których aktywność wpływa na indukcję ekspresji odpowiedniej grupy genów HXT [10]. Istotnym w wykrywaniu i przekazywaniu informacji o zawartości glukozy w podłożu jest również transbłonowe białko receptorowe Gpr1 i powiązane z nim wewnątrzkomórkowe białko Gpa2 działające na zasadzie podjednostki a białka G. Z uwagi na współdziałanie obu tych białek są one niekiedy określane jako system GPCR (ang. G-protein coupled receptor) i odgrywają istotną rolę w szlaku cAMP/PKA. W komórkach drożdży szlak ten jest głównym szlakiem sygnalizacyjnym dostosowującym metabolizm komórkowy do poziomu dostępnych składników odżywczych. Ponadto zaangażowany jest również w regulację wielu innych procesów komórkowych jak wzrost, proliferacja czy odpowiedź na stres. Odbywa się to m.in. poprzez zmiany w procesach glikolizy i oddychania tlenowego, zmiany w ekspresji genów związanych z biogenezą rybosomów i możliwościami biosyntetycznymi komórki oraz poprzez zmiany w ekspresji genów związanych z mechanizmem odpowiedzi na stres a pozostających pod kontrolą czynników transkrypcyjnych Msn2 i Msn4 [10,11]. Poza detekcją zewnątrzkomórkowego stężenia glukozy, równie istotne jest monitorowanie jej stężenia wewnątrzkomórkowego. Przyjmuje się, że ważną rolę w tym wewnątrzkomórkowym szlaku sygnalizacyjnym odgrywa izoforma heksokinazy - Hxk2. Enzym ten, generalnie odpowiedzialny za pierwszą reakcję w szlaku glikolizy, czyli fosforylację glukozy do glukozo-6-fosforanu, okazuje się mieć znacznie w zależnej od glukozy represji szeregu ge- 
nów, w tym uczestniczących w glukoneogenezie czy wykorzystywaniu alternatywnych źródeł węgla [10,50]. Odgrywa kluczową rolę w zależnej od glukozy represji genów kodujących białka uczestniczące w oddychaniu tlenowym [1]. A jak pokazują ostatnie badania delecja genu HXK2 w komórkach drożdży generuje szeroki zakres zmian metabolicznych skutkujący m.in. obniżeniem ogólnych możliwości biosyntetycznych komórki, ale jednocześnie lepszą proteostazą i zwiększonym potencjałem reprodukcyjnym komórek [51].

\section{OGRANICZONE ZDOLNOŚCI REPRODUKCYJNE KOMÓREK I ICH MOŻLIWE PRZYCZYNY}

Przyjmuje się, że najbardziej miarodajnym wyrazem sprawności fizjologicznej komórki są jej możliwości proliferacyjne, bowiem biosynteza kluczowych makromolekul, która musi pokryć zapotrzebowanie zarówno samej komórki jak i tworzonego przez nią pączka (komórki potomnej), wymaga pełnej synchronizacji i znacznych nakładów inwestycyjnych. Wraz z wiekiem u człowieka i innych ssaków obserwuje się stopniowy spadek możliwości proliferacyjnych komórek, co przekłada się na ograniczenie możliwości regeneracyjnych ich organizmów [52,53]. Zjawisko ograniczonej zdolności proliferacyjnej notowane jest także dla pojedynczych komórek drożdży $S$. cerevisiae, bowiem komórka „matka” w ciągu swojego życia może wytworzyć ograniczoną liczbę komórek potomnych [54]. Ograniczone możliwości reprodukcyjne komórek drożdży próbuje się tłumaczyć biorąc pod uwage różnorodne czynniki w tym gromadzenie agregatów białkowych, niestabilność genetyczną i wzrost liczby pozachromosomalnych kółek rDNA czy akumulację uszkodzonych mitochondriów [55]. Alternatywne wyjaśnienie tej kwestii, odnoszące się do relatywnie dużych rozmiarów uzyskiwanych przez komórki, które zakończyły proliferację, przedstawia hipoteza hipertrofii [56,57]. Wskazuje ona na istnienie ścisłego związku pomiędzy tempem wzrostu wielkości komórek a ich możliwościami reprodukcyjnymi [56-58]. Problem hipertrofii w przypadku komórek drożdży ściśle wiąże się z mechanizmem cytokinezy na drodze pączkowania. Pączkowanie bowiem eliminuje możliwość redukcji wielkości komórki "matki”, jak ma to miejsce w przypadku innych komórek eukariotycznych. Tym samym przyczynia się do stopniowego wzrostu jej rozmiarów, skutkując osiąganiem przez komórkę po kilkudziesięciu cyklach wielkości, która uniemożliwia dalszą reprodukcję [56-58]. Jakkolwiek, stan hipertrofii i wynikające $\mathrm{z}$ niego ograniczenie możliwości reprodukcyjnych komórki nie powinny być traktowane tylko w kwestiach parametrów fizycznych. Wielkość komórki ma także istotny wpływ na architekturę wewnątrzkomórkową a wzrost wielkości pociąga za sobą konieczność dostosowania poziomu biosyntezy i dystrybucji poszczególnych składników komórkowych, celem utrzymania ich odpowiednich proporcji względem rozmiarów komórki [57,59]. Stąd też tempo przyrostu wielkości komórki w czasie pojedynczego cyklu wydaje się decydować o potencjalnych możliwościach proliferacyjnych komórki $[56,57,60]$. Tempo przyrostu wielkości komórki, a co za tym idzie szybkość osiągania postulowanego stanu hipertrofii może mieć uwarunkowania metaboliczne. Te z kolei mogą być modyfikowane zarówno przez czynniki genetyczne jak też warunki środowiskowe, spośród których szczególnie istotna wydaje się być dostępność składników odżywczych.

\section{POZIOM GLUKOZY W ŚRODOWISKU VS STAN FIZJOLOGICZNY I MOŻLIWOŚCI REPRODUKCYJNE KOMÓREK}

Bardzo szeroki zakres oddziaływania glukozy na procesy wewnątrzkomórkowe (Ryc. 1) powoduje, że wiele aspektów jej metabolizmu nie zostało jeszcze dokładnie poznanych. Stąd celem badań ujętych w pracy doktorskiej, opartej na cyklu publikacji naukowych, było określenie wpływu glukozy i zmian jej stężenia na szeroko pojęty stan fizjologiczny, metabolizm, potencjał reprodukcyjny i długość życia komórek drożdży S. cerevisiae. W badaniach zastosowano układ eksperymentalny konfrontujący dwa czynniki tj. zarówno zmienne genetyczne (zastosowanie szczepów drożdży pozbawionych wybranych genów biorących udział w wykrywaniu i sygnalizacji zależnej od glukozy) jak i zmienne środowiskowe (różne stężenia glukozy w podłożu hodowlanym). Materiał badawczy stanowiły komórki drożdży S. cerevisiae reprezentujące głównie tło genetyczne BY4741 (szczep dziki; WT ang. wild type) oraz izogeniczne względem niego szczepy pozbawione wybranych genów związanych z metabolizmem glukozy ( $\Delta g p a 2 ; \Delta g p r 1$ oraz $\Delta h x k 2)$. Jako podłoże hodowlane wykorzystywano podłoże YPD ze zmiennymi stężeniami glukozy (0,5\% - warunki restrykcji kalorycznej; $2 \%$ - warunki optymalne; $4 \%$ - warunki nadmiaru kalorii). Takie kompleksowe podejście, wykorzystujące nie tylko warunki restrykcji kalorycznej, ale także wysokie stężenia glukozy jako odpowiednik warunków nadmiaru kalorii wydaje się być szczególnie ważne dla rozwoju obecnej wiedzy w sytuacji, gdy spożywanie nadmiaru kalorii jest powszechne, a ludzkość boryka się z rosnącym problemem otyłości i cukrzycy typu 2. Wyniki badań uzyskane $\mathrm{w}$ toku realizacji pracy doktorskiej wpisują się w działania zmierzające do pełniejszego zrozumienia zależności między zmianami poziomu glukozy, komórkowymi szlakami metabolicznymi a kontrolą wzrostu wielkości komórki i jej możliwościami proliferacyjnymi.

\section{KOMÓRKOWA EKONOMIA DOTYCZACA FERMENTACJI I ODDYCHANIA TLENOWEGO}

Metabolizm komórkowy jest ściśle kontrolowany i stale dostosowywany zarówno do aktualnych potrzeb komórki, jak też do dostępności składników odżywczych w środowisku $[2,7]$. Uzyskane wyniki wskazują, że nadmiar lub ograniczenie dostarczanych kalorii ma istotny wpływ na funkcjonowanie komórki poprzez inicjowanie zmian na poziomie metabolicznym $[47,48]$. Zaobserwowane zmiany wydają się być podyktowane z jednej strony kosztami a z drugiej korzyściami wynikającymi z wykorzystania glukozy w różnych szlakach metabolicznych, sugerując że sprawność fizjologiczna komórki zależy od metabolicznego kompromisu między różnymi sposobami wykorzystania glukozy. Komórki drożdży rosnące $\mathrm{w}$ warunkach dostępności tlenu i w obecności glukozy, uzyskują energię poprzez fermentację [7,50]. I chociaż podczas fermentacji wytwarzana jest stosunkowo niewielka ilość energii, to koszty komórkowe zainwestowane w syntezę enzymów wymaganych dla tego szlaku są niższe w porównaniu z inwestycją jakiej wymaga oddychaniem tlenowe [7]. Na takie wyjaśnienie wskazuje brak istotnych różnic w tempie wzrostu populacji komórek drożdży, zmniejszenie poziomu ATP, a przy tym jednoczesne zwiększenie rozmiarów i biomasy komórek wraz ze wzrastającym w podłożu 
stężeniem glukozy (Ryc. 3A-B; 3D-E). Sugeruje to, że poziom ATP nie determinuje w sposób bezpośredni możliwości biosyntetycznych, a przez to wielkości komórki i w konsekwencji jej zdolności reprodukcyjnych $[47,48]$. Wynika z tego, że nawet jeśli fermentacja, pod względem liczby wytworzonych cząsteczek ATP, jest procesem mniej wydajnym energetycznie to może być postrzegana jako korzystniejsza dla reprodukcji komórek, bowiem w sytuacji dostępności składników odżywczych glukoza może być efektywnie włączana do produkcji podstawowych komponentów budulcowych potrzebnych do tworzenia nowych komórek [2,4]. Sugeruje to, że glikoliza w warunkach tlenowych wydaje się być bardziej efektywnym procesem z biosyntetycznego punktu widzenia.

\section{POCHODNE GLUKOZY VS ZJAWISKO I ZNACZENIE AUTOFLUORESCENCJI}

Wykorzystanie glukozy na drodze glikolizy i szlaku PPP zapewnia komórce pośrednie metabolity węglowe wymagane do biosyntezy jej niezbędnych komponentów $[2,4,8]$. Takie wykorzystanie glukozy przez komórkę oraz fakt, iż niektóre z wytworzonych komponentów komórki mogą posiadać naturalne właściwości fluorescencji, wiążą się ze zjawiskiem autofluorescencji. W przeprowadzonych badaniach wykazano, iż za występujące w komórkach drożdży zjawisko autofluorescencji w głównej mierze odpowiedzialne są tryptofan, ryboflawina i pirydoksyna [8]. Te endogenne fluorofory są bezpośrednio zależne od metabolizmu glukozy, co powoduje, że zmiany w jednym ze szlaków wykorzystania glukozy lub zmiany jej dostępności mogą wpływać na różną zawartość tych metabolitów w komórce. Różne stężenia endogennych fluoroforów nie tylko wpływają na poziom autofluorescencji, ale ze względu na ich właściwości mogą także znacząco modyfikować stan fizjologiczny komórek. W rezultacie pomiar autofluorescencji może dostarczać informacji na temat stanu fizjologicznego komórek w czasie rzeczywistym w natywnych próbkach biologicznych. Z drugiej jednak strony wykrywanie i interpretacja autofluorescencji może przysparzać pewnych trudności głównie ze względu na jednoczesne występowanie w próbkach biologicznych różnych endogennych fluoroforów i nakładanie się ich widm wzbudzenia i emisji. Dodatkowy problem wiąże się z tym, że widma wzbudzenia i emisji niektórych egzogennych fluoroforów wykorzystywanych w szeregu oznaczeń biochemicznych mogą pokrywać się z tymi obserwowanymi dla endogennych fluoroforów. A to z kolei może wpływać na interpretację wyników pomiarów fluorescencji w oznaczeniach biochemicznych. Przykładem tego jak istotna może być to zmiana mogą być dane uzyskane w trakcie oznaczeń wykorzystujących fluorescencyjny analog glukozy 6-NBDG (Ryc. 2A-D). Biorąc pod uwagę te aspekty, uzyskane wyniki badań z jednej strony wskazują na możliwe wykorzystanie pomiarów autofluorescencji dla oceny stanu fizjologicznego komórki, a z drugiej zwracają uwagę na konieczność standaryzowania metod opartych na pomiarze fluorescencji, uwzględniając wyjściowy poziom autofluorescencji, który może wykazywać dużą zmienność w obrębie różnych typów komórek, ale także w zależności od warunków.

\section{ZALEŻNE OD GLUKOZY DROGI PRZEKIEROWANIA METABOLICZNEGO}

Warunki restrykcji kalorycznej i nadmiaru kalorii znacząco modyfikują możliwości biosyntetyczne i ogólny status fizjologiczny komórek drożdży. Zaobserwowano, że w warunkach restrykcji kalorycznej komórki wykazują niewielkie możliwości biosyntetyczne, co może wynikać z przekierowania metabolicznego (ang. metabolic flux) z gli-

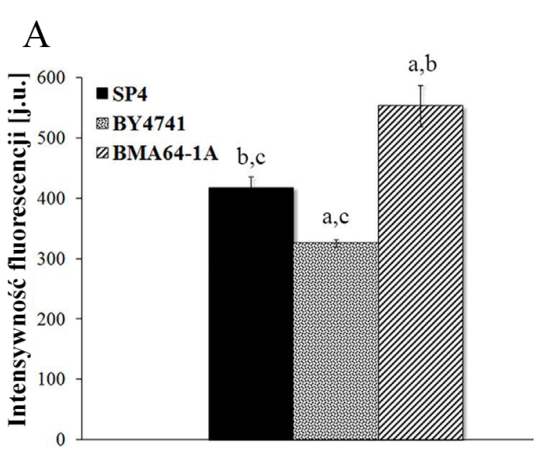

$\mathrm{B}$
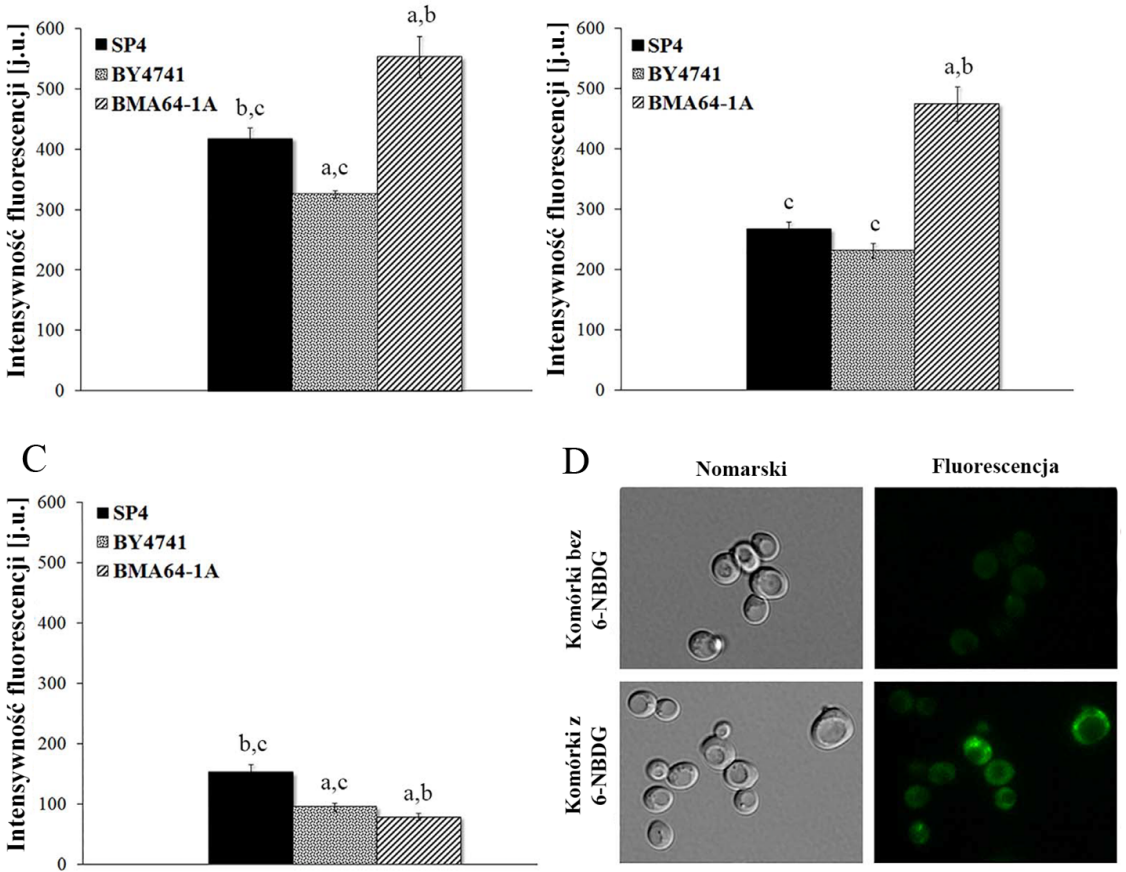

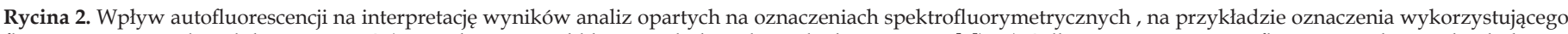

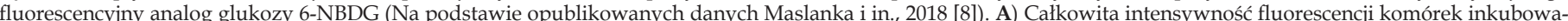

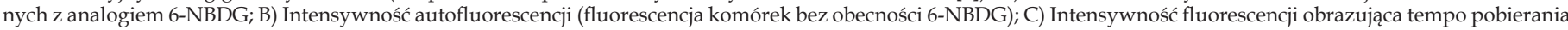

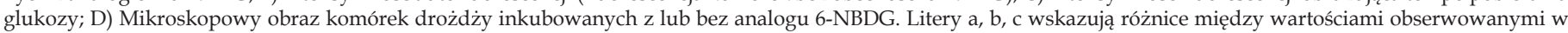
różnych szczepach drożdży: a - różnice względem szczepu SP4, b - różnice względem szczepu BY4741, c - różnice względem szczepu BMA64-1A. p<0,05 
kolizy w kierunku oddychania tlenowego, na co wskazuje m.in. wyższy poziomom ATP notowany w tych warunkach [48,51]. Dane te są zgodne z wynikami prezentującymi związek pomiędzy zwiększeniem długości życia w warunkach restrykcji kalorycznej a zwiększonym oddychaniem tlenowym $[40,45]$. W świetle uzyskanych wyników wydaje się jednak, że zwiększony poziom oddychania tlenowego nie jest przyczyną zwiększenia potencjału reprodukcyjnego, a raczej skutkiem przekierowania metabolicznego [51]. To wyjaśniałoby, dlaczego warunki restrykcji kalorycznej mogą również prowadzić do zwiększenia długości życia w komórkach drożdży niekompletnych oddechowo $\left(\mathrm{rho}^{0}\right)$ [42], u których oddychanie tlenowe nie zachodzi. Z kolei, warunki pełnej dostępności glukozy w środowisku, mogą prowadzić do zwiększonego jej przekierowania metabolicznego w kierunku glikolizy, co zmniejsza poziom ATP, ale jednocześnie zwiększa możliwości biosyntetyczne komórki. Możliwości te są nierozerwalnie związane ze szlakiem PPP, a dotychczasowe wyniki badań wskazują na dodatnią korelację między produkcją biomasy a przekierowaniem metabolicznym w stronę szlaku PPP [61]. Sugeruje to, że warunki nadmiaru kalorii promują wyższy poziom biosyntez komórkowych, prawdopodobnie poprzez przekierowanie metaboliczne w kierunku glikolizy i szlaku PPP. Ważnym argumentem na korzyść założenia, iż aktywność szlaku PPP jest związana z możliwościami biosyntetycznymi, okazały się wyniki uzyskane dla komórek szczepów z delecją genów GPA2 i GPR1. Wykazywały one bowiem względem komórek szczepu dzikiego niższe tempo pobierania glukozy (Ryc. 3C), znacznie niższą aktywność enzymów szlaku PPP, a jednocześnie niższe możliwości biosyntetyczne (Ryc. 3E) [48].

\section{GLUKOZA A GENERACJA RFT W KOMÓRKACH DROŻDŻY}

Różne stężenia glukozy oraz możliwości jej wewnątrzkomórkowych przekształceń niewątpliwie wiążą się także ze zmianami metabolicznymi, których powszechnie znanym efektem ubocznym jest generacja RFT. W przypadku badań prowadzonych z wykorzystaniem drożdży wartym podkreślenia jest fakt niejednoznaczności wyników dotyczących generacji RFT w warunkach restrykcji kalorycznej $[41,43,44]$. W tej kwestii istotnych danych dostarczyły badania wykonane w ramach pracy doktorskiej obrazujące poziom generacji RFT. Wykazały one, że generacja RFT w komórkach drożdży wzrasta wraz ze wzrostem stężenia glukozy w podłożu, przy czym odnotowano również, że zmniejszenie tempa pobierania glukozy może działać w kierunku obniżenia poziomu generacji RFT. Najwyższy i nieco zaskakujący poziom generacji RFT zaobserwowano w warunkach nadmiaru kalorii, w których komórki drożdży prowadzą metabolizm fermentacyjny (Ryc. 4A-B). Dało to podstawę do wnioskowania o obecności poza-mitochondrialnych źródeł RFT. Taką możliwość potwierdziły dodatkowo analizy stanu funkcjonalnego mitochondriów w warunkach różnego stężenia glukozy (Ryc. 4C) oraz analizy poziomu generowania RFT w komórkach niekompletnych oddechowo, które nie są zdolne do prowadzenia oddychania tlenowego. Potwierdzenie obecności poza-mitochondrialnych źródeł generowania RFT w komórkach drożdży wzmacniają niedawne badania, w których zaobserwowano niezależny od aktywności mitochondriów wzrost poziomu RFT w komórkach drożdży hodowanych w warunkach stresowych wynikających z niedoboru wapnia [62] oraz odkrycie białka Yno1, będącego jak do tej pory

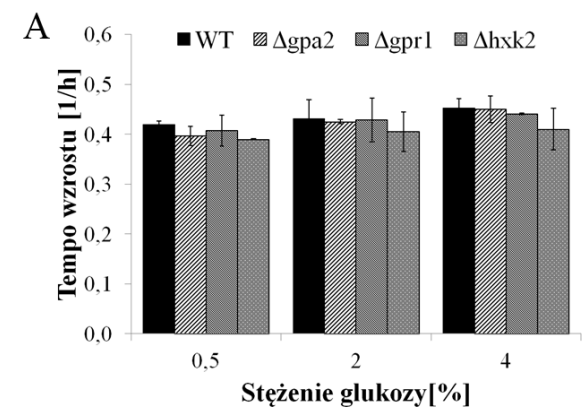

D

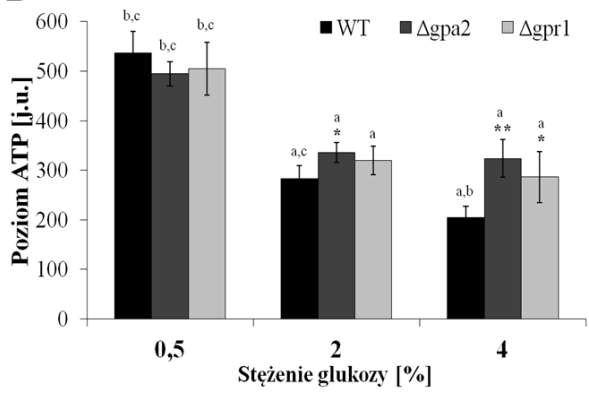

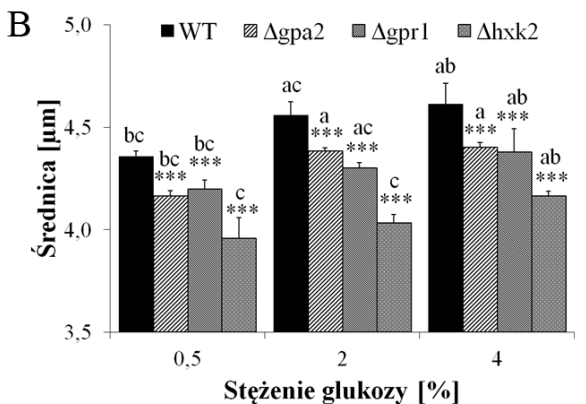

$\mathrm{E}$

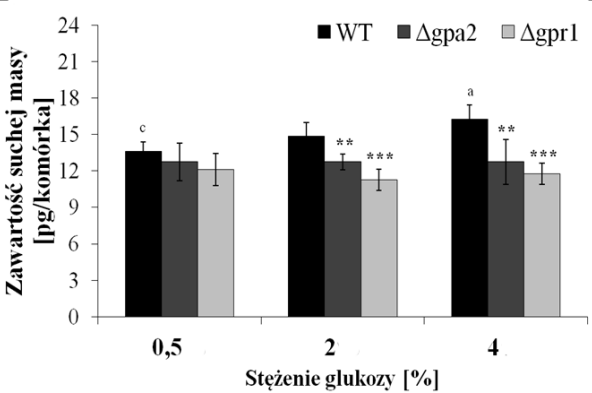

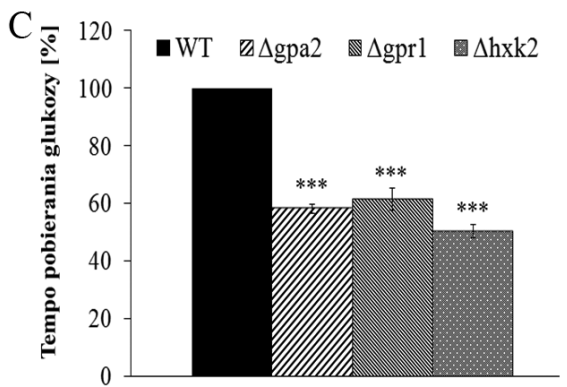

$\mathrm{F}$

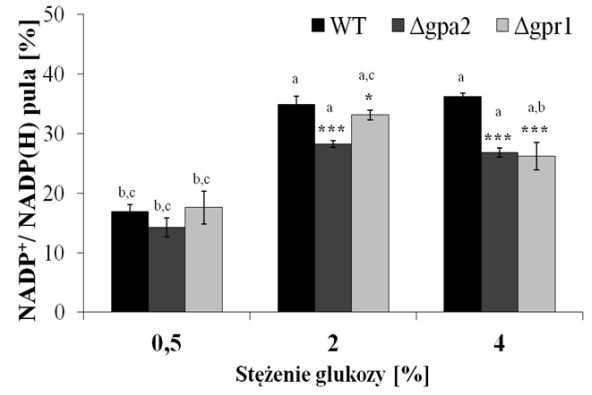

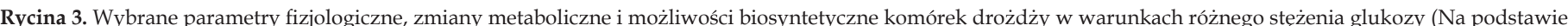

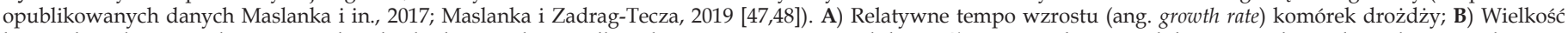

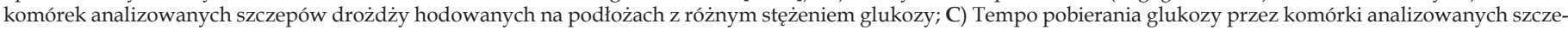

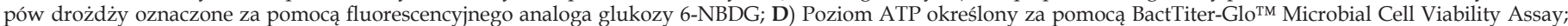

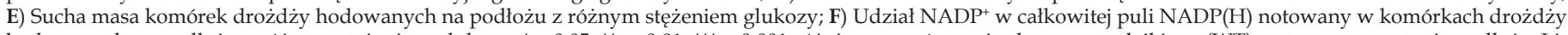

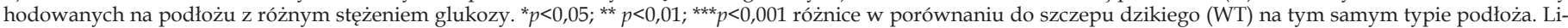

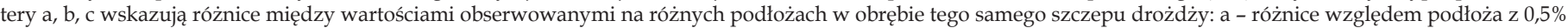
glukozą, b - różnice względem podłoża z 2\% glukozą, c - różnice względem podłoża z 4\% glukozą. p<0,05 

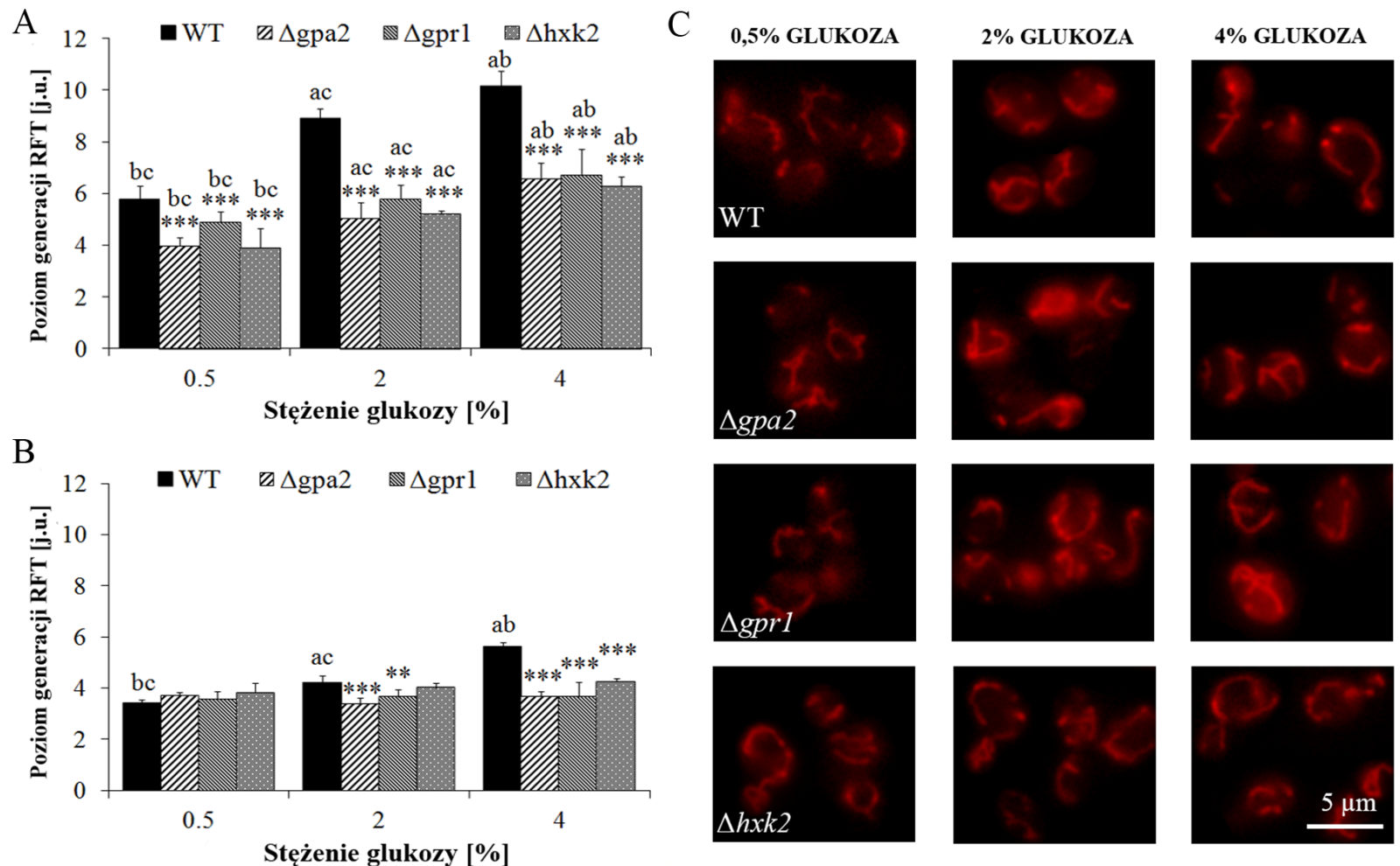

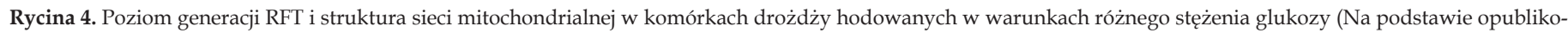

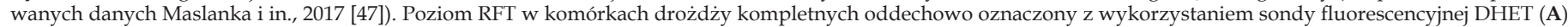

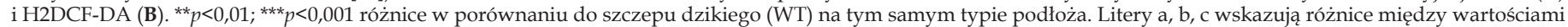

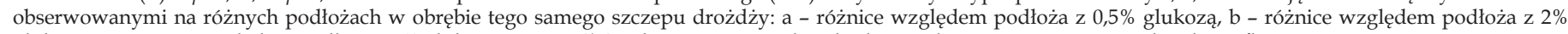

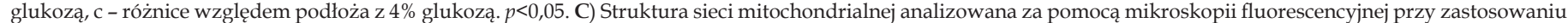
barwnika fluorescencyjnego Rodaminy B. Powiększenie 1000×

jedyną poznaną drożdżową oksydazą NADPH [63]. Wyniki te sugerują potrzebę zmiany, dominującego $\mathrm{w}$ badaniach prowadzonych z wykorzystaniem drożdży, poglądu mówiącego, iż mitochondria są głównym i praktycznie jedynym komórkowym źródłem RFT [47]. Zwiększony poziom generacji RFT w komórkach drożdży hodowanych na podłożach zawierających wysokie stężenia glukozy może mieć związek z wyższą aktywnością szlaku cAMP/PKA. Aktywny szlak cAMP/PKA z jednej strony bowiem promuje biosyntezę białka poprzez indukcję biogenezy rybosomów, natomiast z drugiej strony zmniejsza możliwości odpowiedzi na stres poprzez tłumienie ekspresji genów będących pod kontrolą czynników transkrypcyjnych Msn2 i Msn4 [11]. Oba te efekty mogą być połączone z wyższym poziomem RFT obserwowanym dla komórek hodowanych na podłożach zawierających 2 i $4 \%$ stężenie glukozy.

\section{POTENCJAŁ REPRODUKCYJNY KOMÓREK W WARUNAKCH RÓŻNEGO STEZŻENIA GLUKOZY I JEGO ZWIAZZEK Z MOŻLIWOŚCIAMI BIOSYNTETYCZNYMI}

Wszelkie aspekty energetyczne, metaboliczne czy też związane z odpowiedzią na stres znajdują swoje odzwierciedlenie w sprawności reprodukcyjnej komórki. Jest ona ważna zarówno w przypadku organizmów jednokomórkowych, ponieważ warunkuje utrzymanie ich populacji, jak i w przypadku organizmów wielokomórkowych, u których warunkuje wzrost, regenerację czy też ogólnie pojętą homeostazę liczbową ko- mórek. Uzyskane wyniki sugerują, że potencjał reprodukcyjny komórki drożdży jest zależny od metabolicznego kompromisu między różnymi drogami wykorzystania glukozy, ze szczególnym uwzględnieniem szlaków biosyntetycznych. Analiza potencjału reprodukcyjnego komórek drożdży szczepu dzikiego wykazała, iż komórki hodowane w warunkach restrykcji kalorycznej posiadają wyższy potencjał reprodukcyjny w porównaniu do komórek hodowanych na podłożu zawierającym optymalne (2\%) stężenie glukozy [48], a wynik ten znajduje swoje potwierdzenie również $\mathrm{w}$ danych literaturowych [46]. Jednak, co jest ważniejsze i nie było wcześniej prezentowane, wykazano, że nadmiar kalorii znacząco zmniejsza potencjał reprodukcyjny komórki. Istnieje zatem ścisła negatywna korelacja między stężeniem glukozy $\mathrm{w}$ podłożu hodowlanym a potencjałem reprodukcyjnym komórki (Ryc. 5).

Jedna z możliwości wyjaśnienia tej kwestii ściśle łączy się z założeniami hipotezy hipertrofii, wskazującej wielkość komórki, a zwłaszcza tempo przyrostu wielkości komórki na generację jako czynniki determinujące potencjał reprodukcyjny komórek drożdży $[57,59]$. Przeprowadzone badania z jednej strony potwierdziły istnienie silnej korelacji między wielkością komórki a jej potencjałem reprodukcyjnym a z drugiej dostarczyły nowych danych na temat metabolicznej regulacji wielkości związanej ze sposobem wykorzystania glukozy, co niewątpliwie wpływa również na potencjał reprodukcyjny komórek. Komórki o większym rozmiarze obserwowane w warunkach nadmiaru kalorii charakteryzowały się obniżonym 


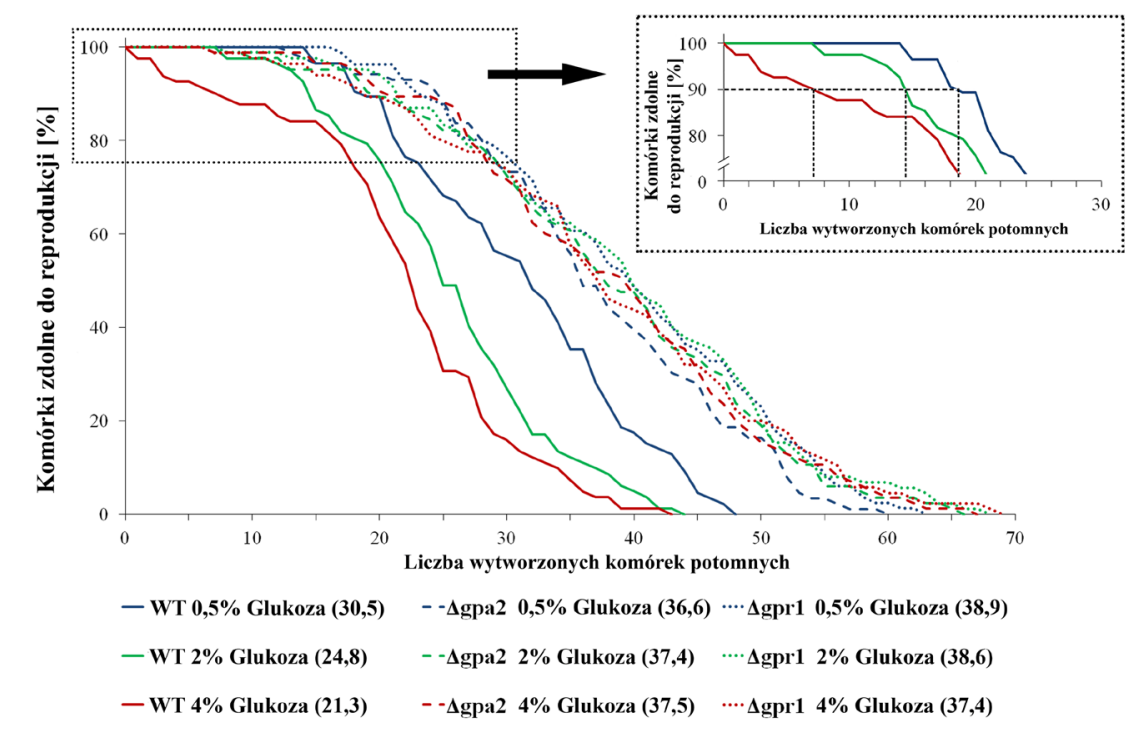

\begin{tabular}{|c|c|c|c|c|}
\hline & \multirow[b]{2}{*}{ Szczep } & \multicolumn{3}{|c|}{ Stężenie glukozy [\%] } \\
\hline & & 0,5 & 2 & 4 \\
\hline $\begin{array}{l}\text { Potencjał reprodukcyjny } \\
\text { (liczba komórek potomnych) }\end{array}$ & $\begin{array}{l}\text { WT (BY4741) } \\
\text { Agpa2 } \\
\text { sgpr1 }\end{array}$ & $\begin{array}{l}30.5 \pm 9.1^{b . c} \\
36.6 \pm 10.7 \\
38.9 \pm 11.6\end{array}$ & $\begin{array}{l}24.8 \pm 8.1^{\mathrm{a} . \mathrm{c}} \\
37.4 \pm 13.0^{\cdots} \\
38.6 \pm 13.1^{\cdots}\end{array}$ & $\begin{array}{l}21.3 \pm 9.1^{2 . b} \\
37.5 \pm 12.4^{\ldots .} \\
37.4 \pm 13.7^{\ldots}\end{array}$ \\
\hline $\begin{array}{l}\text { Reprodukcyjna długość życia } \\
\text { (czas - godziny) }\end{array}$ & $\begin{array}{l}\text { WT (BY4741) } \\
\text { Agpa2 } \\
\text { Agpr1 }\end{array}$ & $\begin{array}{l}78.9 \pm 31.3^{b . c} \\
78.0 \pm 29.8 \\
81.9 \pm 27.6\end{array}$ & $\begin{array}{l}56.4 \pm 25.0^{\circ} \\
87.0 \pm 31.7 \\
83.4 \pm 29.4\end{array}$ & $\begin{array}{l}49.9 \pm 25.8^{2} \\
82.2 \pm 32.1 \ldots \\
79.0 \pm 30.1\end{array}$ \\
\hline
\end{tabular}

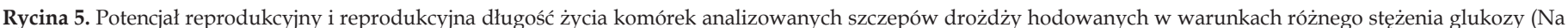

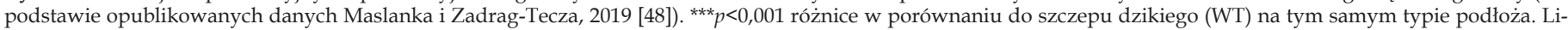

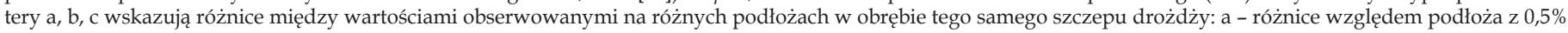
glukozą, b - różnice względem podłoża z 2\% glukozą, c - różnice względem podłoża z $4 \%$ glukozą. $p<0,05$

potencjałem reprodukcyjnym i odwrotnie komórki hodowane w warunkach restrykcji kalorycznej charakteryzowała mniejsza wielkość, ale jednocześnie wyższy potencjał reprodukcyjny (Ryc. 6A-B). Jak podają dane literaturowe odwrotna zależność między potencjałem reprodukcyjnym, długością życia i rozmiarem komórki jest obserwowana także w niektórych typach komórek ssaczych i ludzkich $[64,65]$. Pośrednio wskazują na to również dane dotyczące komórek osób borykających się z problemem cukrzycy typu 2 i otyłości, u których obserwowano zaburzenia w regulacji wzrostu komórki prowadzące do fenotypu hipertrofii i zatrzymania proliferacji $[17,18]$. Związek między wielkością komórki a glukozą opiera się na jej wykorzystaniu w procesach biosyntetycznych. Stąd też większe rozmiary komórek i jednocześnie obniżony potencjał reprodukcyjny w warunkach nadmiaru kalorii może być wynikiem zwiększonego przekierowania glukozy w kierunku procesów biosyntetycznych komórki [48].

Na taką możliwość wskazują dane dotyczące suchej masy komórek oraz zmian $w$ proporcji kofaktorów NADP+ i NADPH (Ryc. 3E-F). Zawartość suchej masy komórek wyraźnie koreluje z potencjałem reprodukcyjnym i wielkością komórki. Wzrostowi suchej masy komórek towarzyszy wzrost wielkości komórki, ale równocześnie spadek ich potencjału reprodukcyjnego i odwrotnie. To sugeruje, że istnieje ścisły związek między wydajnością biosyntetyczną, wielkością komórki a jej potencjałem reprodukcyjnym [48]. Z kolei zaobserwowany wzrost udziału NADP+ w całkowitej puli NADP $(\mathrm{H})$ może być spowodowany zwiększonym zużyciem NADPH wynikającym z wymagań reakcji anabolicznych, bowiem według danych literaturowych procesy biosyntetyczne wymagają utlenienia NADPH do NADP+ w ilości ok. 6,5 mmola na 1 g biomasy [66]. Taką możliwość potwierdzają również badania prowadzone na komórkach ludzkich prezentujące spadek wartości stosunku NADPH/NADP+ z równoczesnym wzrostem poziomu NADP+ w sytuacji zwiększonych potrzeb anabolicznych komórki [51,67].

\section{SZLAK CAMP/PKA I JEGO ROLA W ODPOWIEDZI KOMÓREK DROŻDŻY NA RÓŻNE STĘŻENIA GLUKOZY}

W komórkach drożdży możliwości biosyntetyczne oraz wielkość komórki są zależne od szlaku cAMP/PKA. Szlak ten dostosowuje bowiem metabolizm komórkowy do poziomu dostępnych składników odżywczych. Na bazie wyników uzyskanych dla szczepu dzikiego założono, że w warunkach nadmiaru kalorii (w których potencjał reprodukcyjny komórek był obniżony) aktywność szlaku cAMP/PKA jest zwiększona, podczas gdy zmniejsza się ona $w$ warunkach restrykcji kalorycznej. W celu sprecyzowania roli szlaku cAMP/PKA w powiązaniu między możliwościami biosyntetycznymi komórki a jej potencjałem reprodukcyjnym zastosowano szczepy $\Delta g p a 2 \mathrm{i}$ $\Delta g p r 1$ o zaburzonej aktywności tego szlaku. Uzyskane wyniki pokazały, że w warunkach nadmiaru kalorii potencjał reprodukcyjny komórek szczepów $\Delta g p a 2$ i $\Delta g p r 1$ był wyższy w porównaniu z komórkami szczepu dzikiego i co więcej wartość 
A
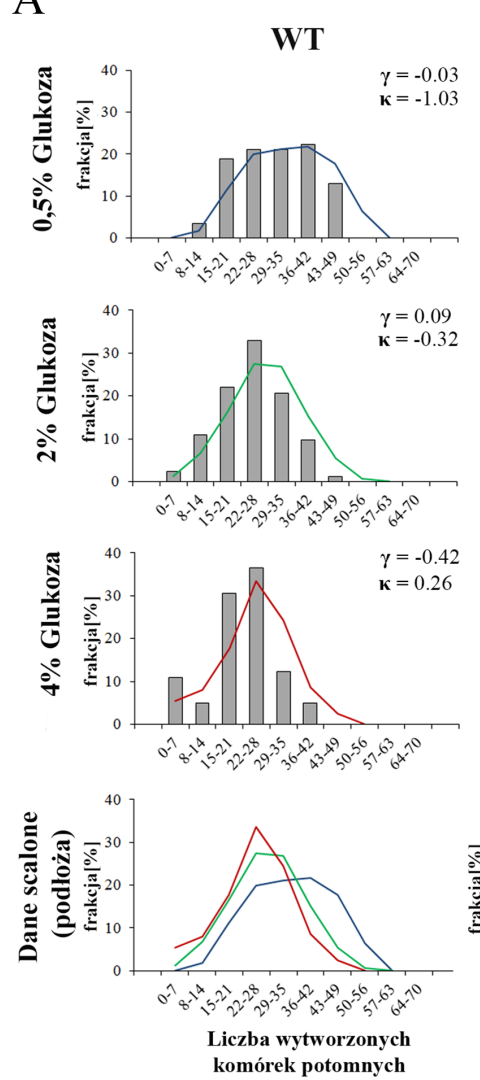

B
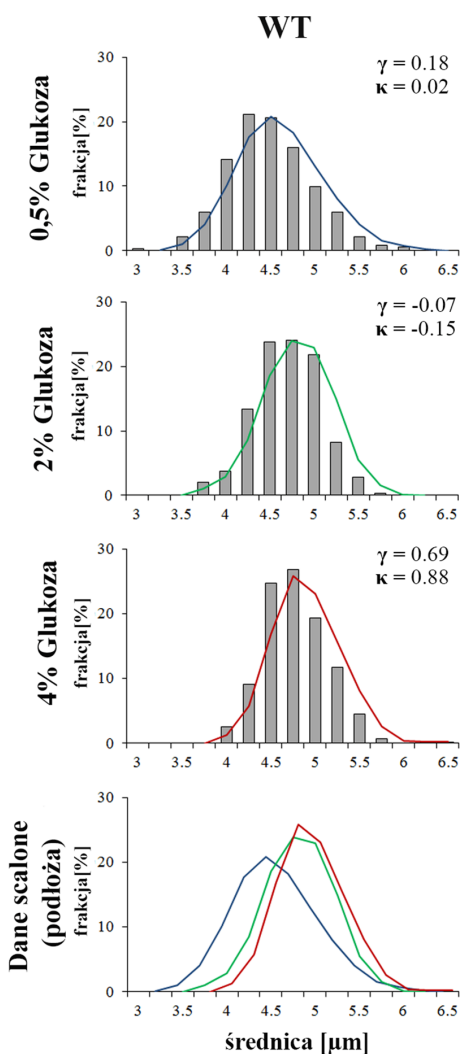

Agpa2
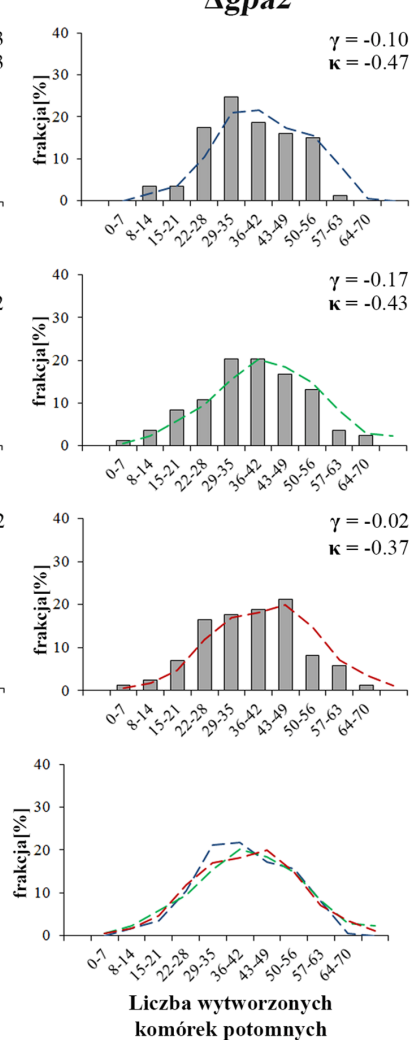

\gpa2
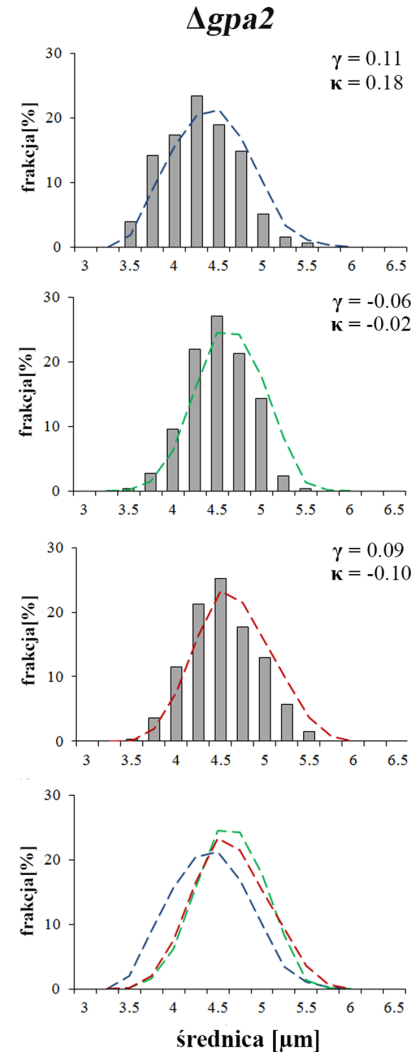

Agpr1
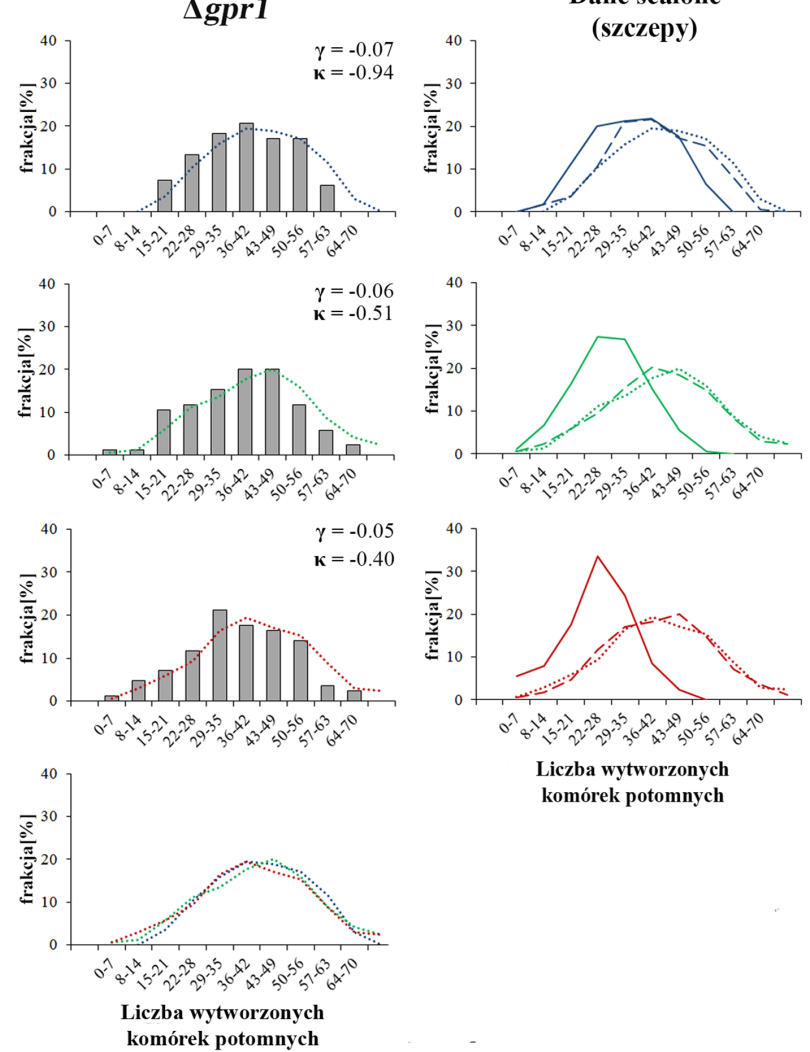
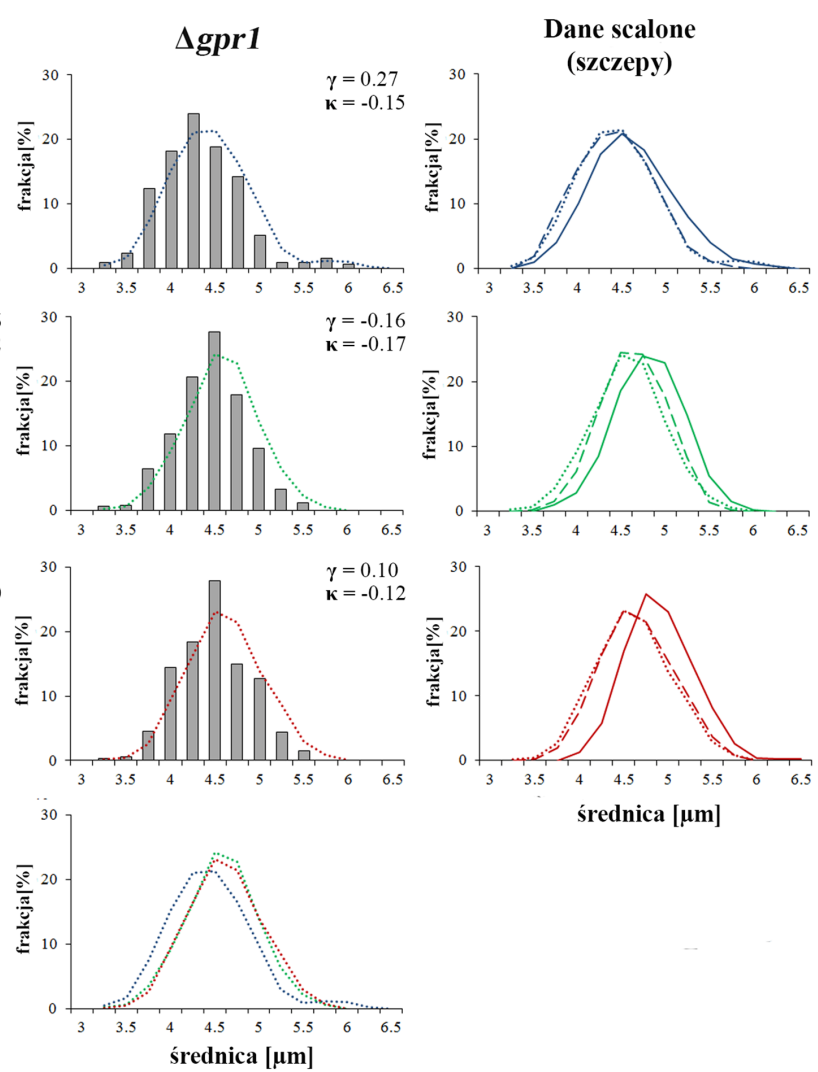

średnica $[\mu \mathrm{m}]$

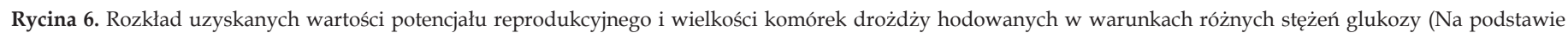

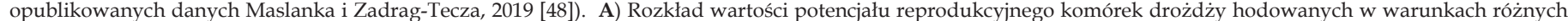
stężeń glukozy; B) Rozkład wartości wielkości komórki w populacji komórek drożdży hodowanych w warunkach różnych stężeń glukozy. $\mathrm{k}$ - kurtoza; $\gamma$ - skośność 
potencjału reprodukcyjnego dla komórek tych szczepów była podobna, niezależnie od stężenia glukozy w podłożu. Wskazuje to, że poprzez obniżenie aktywności szlaku cAMP/PKA, nawet w sytuacji wysokiego zewnątrzkomórkowego stężenia glukozy, można utrzymać potencjał reprodukcyjny komórki na stosunkowo wysokim poziomie. Wysokie możliwości reprodukcyjne obserwowane dla komórek szczepów $\Delta g p a 2$ i $\Delta g p r 1$ wydają się mieć związek z niższymi możliwościami biosyntetycznymi notowanymi dla tych komórek. Zaobserwowano w ich przypadku zarówno niższą zawartość suchej masy komórki i niższą aktywność enzymów szlaku PPP, jak też mniejsze wykorzystanie NADPH w porównaniu z komórkami szczepu dzikiego [48]. Dodając do tego dane literaturowe prezentujące niższą zawartość białka i obniżone tempo jego syntezy w komórkach szczepów $\Delta g p a 2$ i $\Delta g p r 1$ [68], niewątpliwie wskazuje to, że potencjał reprodukcyjny komórki jest związany zarówno z wielkością komórki jak i jej możliwościami biosyntetycznymi.

\section{ZEWNATRZKOMÓRKOWE VS WEWNĄTRZKOMÓRKOWE STĘŻENIE GLUKOZY}

Zastosowanie mutantów delecyjnych odnośnie wybranych genów związanych z metabolizmem glukozy pozwoliło wykazać, że rozmiar komórki i jej możliwości biosyntetyczne są ściślej skorelowane z tempem pobierania glukozy aniżeli z jej stężeniem pozakomórkowym (Ryc. 3B-C; 3E). Nawet wówczas gdy pozakomórkowe stężenie glukozy jest wysokie, obniżenie tempa pobierania glukozy (np. na skutek obniżenia aktywności szlaku cAMP/PKA) może utrzymać mniejszy rozmiar komórki w porównaniu z komórkami o niezaburzonym poborze glukozy. Sugeruje to, że wewnątrzkomórkowy poziom glukozy i sygnalizacja od niej zależna są ważniejsze aniżeli jej poziom zewnątrzkomórkowy $[47,48]$. Założenie takie, potwierdzają również coraz liczniejsze badania prezentujące, że nie ma prostej zależności między fizjologią komórki, jej tempem wzrostu a wykrywaniem glukozy w podłożu. Ważnym aspektem wydaje się właśnie tempo pobierania glukozy, bowiem koordynowanie wzrostu komórki i postęp cyklu komórkowego wymaga współdziałania zewnątrzkomórkowej jak i wewnątrzkomórkowej sygnalizacji warunkowanej glukozą $[11,69]$.

\section{MNIEJ ZNACZY WIECCEJ CZY RACZEJ WIĘCEJ ZNACZY MNIEJ}

Powszechnym jest pogląd o pozytywnym wpływie restrykcji kalorycznej na długość życia wielu organizmów. Ponadto pojawiają się także przesłanki o negatywnym wpływie nadmiaru energii i ilości dostarczanych kalorii na długość życia organizmów. Stąd w badaniach sprawdzono także wpływ różnych stężeń glukozy na długość życia komórek drożdży. Uzyskane wyniki pokazały notowane wcześniej zależności jak na przykład fakt, że post-reprodukcyjna długość życia komórki drożdży jest ujemnie skorelowana z liczbą wyprodukowanych przez nią komórek potomnych czy fakt, że wartość całkowitej długości życia jest porównywalna między komórkami różnych szczepów drożdży, pomimo różnic w ich zdolnościach reprodukcyjnych [70]. Jednakże, po raz pierwszy w przypadku komórek drożdży odnotowano, iż całkowita dłu-

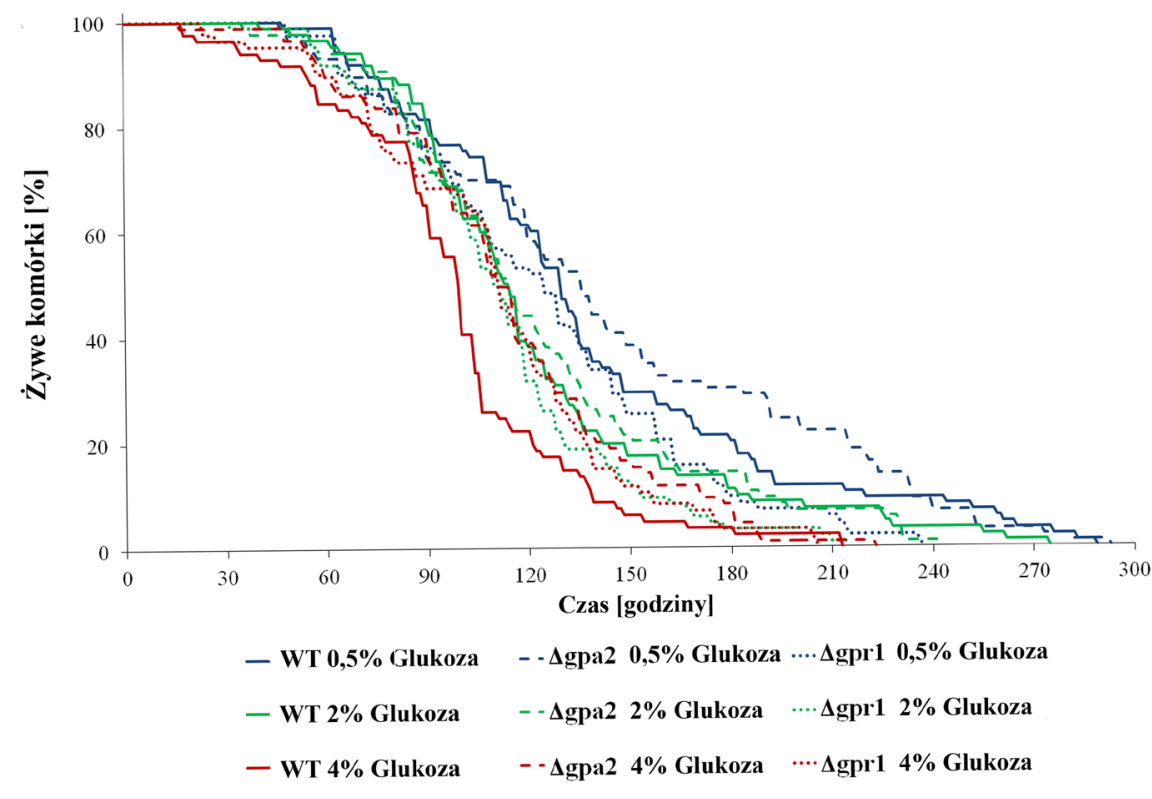

\begin{tabular}{lllcc} 
& & \multicolumn{3}{c}{ Stężenie glukozy [\%] } \\
\cline { 3 - 5 } & \multicolumn{1}{c}{ Szczep } & \multicolumn{1}{c}{0,5} & 2 & 4 \\
Całkowita długość życia & WT (BY4741) & $137.8 \pm 55.8^{\mathrm{c}}$ & $121.8 \pm 46.5^{\mathrm{c}}$ & $97.6 \pm 36.5^{\mathrm{a}, \mathrm{b}}$ \\
(czas - godziny) & $\Delta$ gpa2 & $144.8 \pm 63.1^{\mathrm{b} . c}$ & $122.5 \pm 45.6^{\mathrm{a}}$ & $113.3 \pm 38.6^{* * \mathrm{a}}$ \\
& $\Delta$ gpr1 & $125.2 \pm 44.0^{\mathrm{c}}$ & $111.3 \pm 34.9$ & $109.6 \pm 38.8^{*, \mathrm{a}}$
\end{tabular}

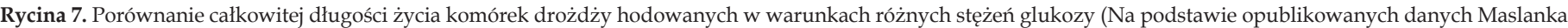

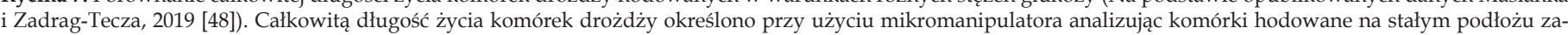

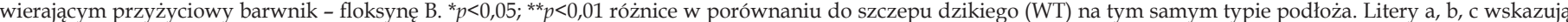

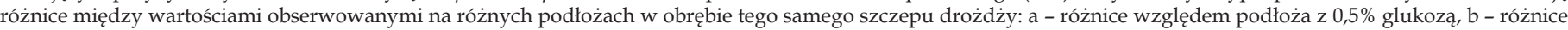
względem podłoża z $2 \%$ glukozą, c - różnice względem podłoża z $4 \%$ glukozą. $p<0,05$ 
gość życia jest wyraźnie skrócona w warunkach nadmiaru kalorii, natomiast wydaje się być porównywalna w warunkach restrykcji kalorycznej i w warunkach optymalnych (Ryc. 7).

Uzyskane wyniki z jednej strony potwierdzają, że warunki restrykcji kalorycznej mogą poprawiać sprawność fizjologiczną komórek, co przejawia się m.in. zmniejszeniem generacji RFT oraz zwiększonym potencjałem reprodukcyjnym. Jednakże, restrykcja kaloryczna wydaje się nie zwiększać znacząco całkowitej długości życia komórek drożdży. Z drugiej strony uzyskane wyniki pokazują, że warunki nadmiaru kalorii prowadzą zarówno do zaburzeń w fizjologii komórki (zwiększona generacja RFT, zmniejszony potencjał reprodukcyjny) jak też skrócenia całkowitej długości życia komórek drożdży. Szczegółowa analiza uzyskanych wyników i szeroki przegląd literatury, stały się podstawą do stworzenia modeli prezentujących zmiany metabolizmu komórki w zależności od stężenia glukozy oraz ich wpływ na wielkość i potencjał reprodukcyjny komórek drożdży (Ryc. 8). Jakkolwiek wyniki i ich objaśnienia ujęte $\mathrm{w}$ pracy nie mogą być bezpośrednio porównywane $\mathrm{z}$ wynikami badań dotyczących restrykcji kalorycznej przeprowadzonych na innych często wielokomórkowych organizmach modelowych, to $\mathrm{w}$ niektórych obszarach mogą występować między nimi swoiste analogie. Niewątpliwie takimi analogia- mi są ogólny sposób działania restrykcji kalorycznej a także szkodliwość nadmiarowej podaży składników odżywczych.

\section{PODSUMOWANIE}

Szeroka analiza konsekwencji nadmiaru i restrykcji kalorycznej dla komórek drożdży $S$. cerevisiae i wnioski ujęte w pracy przyczyniają się do pełniejszego zrozumienia regulacji metabolizmu glukozy na poziomie komórkowym. Z uwagi na podobieństwo szlaków metabolicznych, dane z przeprowadzonych badań mogą posłużyć jako materiał porównawczy dla badań prowadzonych na innych typach komórek. Co więcej sformułowane na podstawie uzyskanych wyników wnioski mogą okazać się pomocne w analizach dotyczących funkcjonowania komórek narażonych na wysokie stężenia glukozy, co ma miejsce m.in. w przypadku osób chorych na cukrzycę.

Do najważniejszych wniosków przeprowadzonych badań można zaliczyć: (1) wykazanie, że w komórce istnieje specyficzny kompromis metaboliczny pomiędzy różnymi sposobami wykorzystania glukozy, (2) wewnątrzkomórkowe wykorzystanie glukozy jest zależne od jej stężeniem w otoczeniu oraz tempa jej pobierania, (3) stężenie glukozy w podłożu hodowlanym ma wpływ na poziom generowanych RFT,
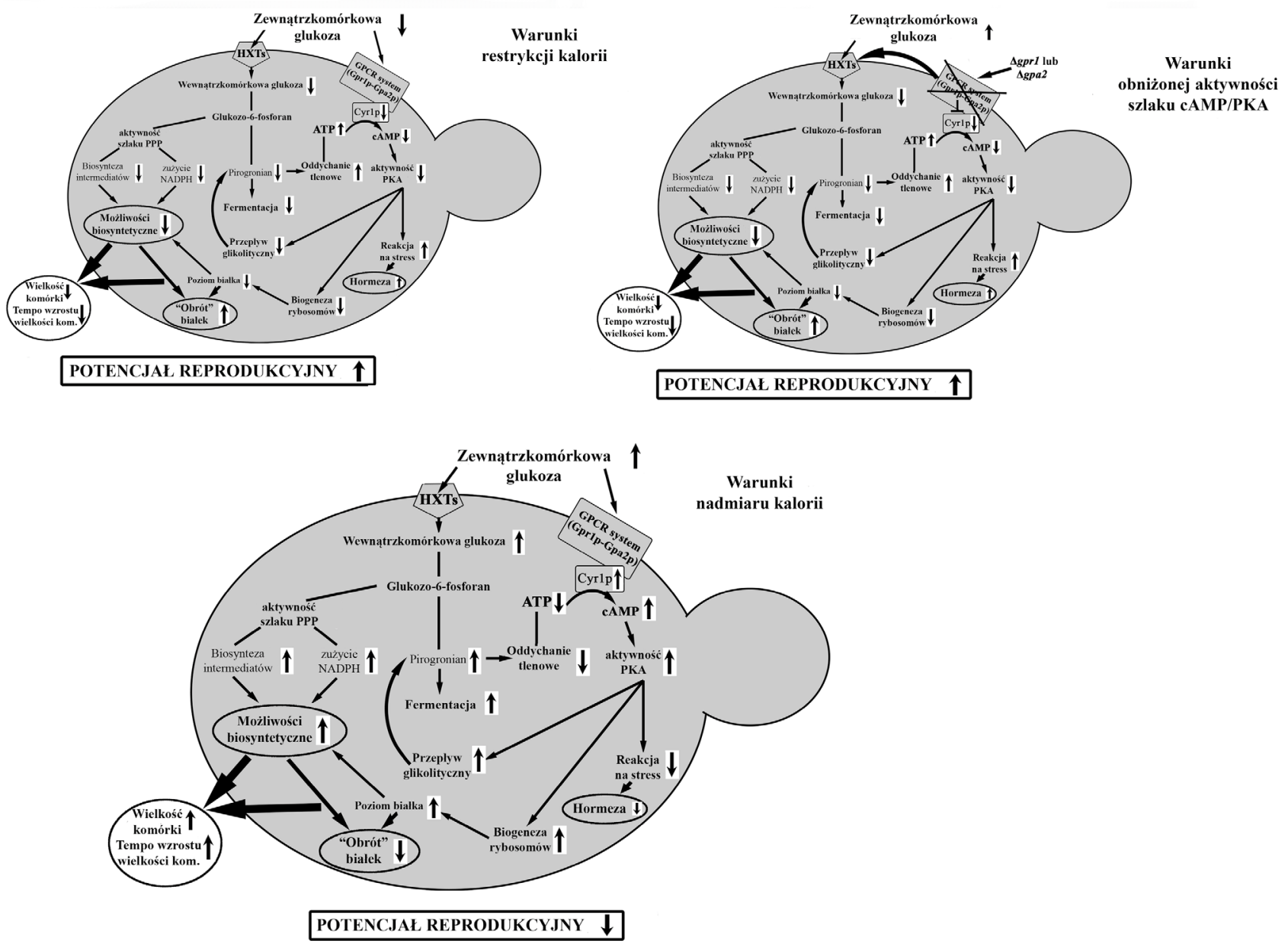

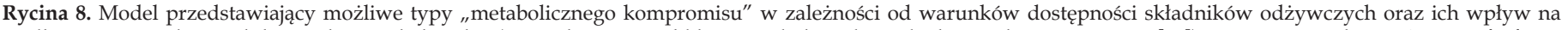

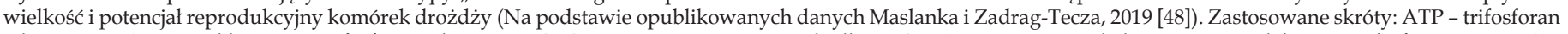

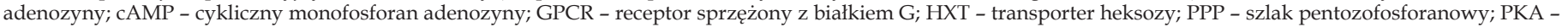
kinaza białkowa A. 
przy czym istotna ich część jest generowana w sposób poza-mitochondrialny, (4) istnieje silna zależność między stężeniem glukozy, stanem fizjologicznym komórek drożdży, ich wielkością i możliwościami biosyntetycznymi a potencjałem reprodukcyjnym, (5) warunki nadmiaru kalorii negatywnie wpływają na sprawność fizjologiczną, potencjał reprodukcyjny a także całkowitą długość życia komórki.

\section{PIŚMIENNICTWO}

1. Rodrigues F, Ludovico P, Leão C (2006) Sugar Metabolism in Yeasts: an Overview of Aerobic and Anaerobic Glucose Catabolism. W: Gabor $P$, Rosa C (red) The Yeast Handbook. Biodiversity and Ecophysiology of Yeasts. Springer: Berlin, str. 101-121

2. Vander Heiden MG, Cantley LC, Thompson CB (2009) Understanding the Warburg effect: the metabolic requirements of cell proliferation. Science 324: 1029-1033

3. Diaz-Ruiz R, Rigoulet M, Devin A (2011) The Warburg and Crabtree effects: On the origin of cancer cell energy metabolism and of yeast glucose repression. Biochim Biophys Acta 1807: 568-576

4. Folmes CD, Terzic A (2016) Energy metabolism in the acquisition and maintenance of stemness. Semin Cell Dev Biol 52: 68-75

5. Hu C, Fan L, Cen P, Chen E, Jiang Z, i in. (2016) Energy Metabolism Plays a Critical Role in Stem Cell Maintenance and Differentiation. Int J Mol Sci 17: 253

6. Schuster S, Boley D, Möller P, Stark H, Kaleta C (2015) Mathematical models for explaining the Warburg effect: a review focussed on ATP and biomass production. Biochem Soc Trans 43: 1187-1194

7. Nilsson A, Nielsen J (2016) Metabolic Trade-offs in Yeast are Caused by F1F0-ATP synthase. Sci Rep 6: 22264

8. Maslanka R, Kwolek-Mirek M, Zadrag-Tecza R (2018) Autofluorescence of yeast Saccharomyces cerevisiae cells caused by glucose metabolism products and its methodological implications. J Microbiol Methods 146: 55-60

9. Magier Z, Jarzyna R (2013) [The role of glucose transporters in human metabolic regulation]. Postepy Biochem 59: 70-82

10. Rødkaer SV, Faergeman NJ (2014) Glucose- and nitrogen sensing and regulatory mechanisms in Saccharomyces cerevisiae. FEMS Yeast Res 14: 683-696

11. Busti S, Coccetti P, Alberghina L, Vanoni M (2010) Glucose signaling-mediated coordination of cell growth and cell cycle in Saccharomyces cerevisiae. Sensors (Basel) 10: 6195-6240

12. Simpson IA, Dwyer D, Malide D, Moley KH, Travis A, i in. (2008) The facilitative glucose transporter GLUT3: 20 years of distinction. Am J Physiol Endocrinol Metab 295: E242-53

13. Herman MA, Kahn BB (2006) Glucose transport and sensing in the maintenance of glucose homeostasis and metabolic harmony. J Clin Invest 116: 1767-1775

14. Rosen ED, Spiegelman BM (2006) Adipocytes as regulators of energy balance and glucose homeostasis. Nature 444: 847-853

15. Kalsbeek A, Yi CX, La Fleur SE, Fliers E (2010) The hypothalamic clock and its control of glucose homeostasis. Trends Endocrinol Metab, 21: $402-410$

16. Chrościcki P, Usarek M, Bryla J (2013) [The role of biological clock in glucose homeostasis]. Postepy Hig Med Dosw (Online) 67: 569-583

17. Morocutti A, Earle KA, Sethi M, Piras G, Pal K, i in. (1996) Premature senescence of skin fibroblasts from insulin-dependent diabetic patients with kidney disease. Kidney Int 50: 250-256

18. Liu L, Hu X, Cai GY, Lv Y, Zhuo L, i in. (2012) High glucose-induced hypertrophy of mesangial cells is reversed by connexin 43 overexpression via PTEN/Akt/mTOR signaling. Nephrol Dial Transplant 27: 90-100

19. Suji G, Sivakami S (2004) Glucose, glycation and aging. Biogerontology. 5: 365-373

20. Gupte SA (2010) Targeting the Pentose Phosphate Pathway in SyndromeX-related Cardiovascular Complications. Drug Dev Res 71: 161-167
21. Yu J, Wu Y, Yang P (2016) High glucose-induced oxidative stress represses sirtuin deacetylase expression and increases histone acetylation leading to neural tube defects. J Neurochem 137: 371-383

22. Mrowicka M (2011) Znaczenie zaburzeń układu prooksydacyjno-antyoksydacyjnego dla etiopatologii cukrzycy. Postepy Hig Med Dosw. 65: 534-541

23. International Diabetes Federation. IDF Diabetes Atlas nineth edition (2019) Brussels. Available at: http:/ / www.diabetesatlas.org

24. Kahn CR (1994) Insulin Action, Diabetogenes, and the Cause of Type II Diabetes. Diabetes. 43: 1066-1084

25. Zimmet P, Thomas CR (2003) Genotype, obesity and cardiovascular disease--has technical and social advancement outstripped evolution? J Intern Med 254: 114-125

26. Biliński T, Paszkiewicz T, Zadrag-Tecza R (2015) Energy excess is the main cause of

27. Roth LW, Polotsky AJ (2012) Can we live longer by eating less? A review of caloric restriction and longevity. Maturitas 71: 315-319

28. Fontana L, Partridge L (2015) Promoting health and longevity through diet: from model organisms to humans. Cell 161: 106-118

29. Mattson MP, Longo VD, Harvie M (2016) Impact of Intermittent Fasting on Health and Disease Processes. Ageing Research Reviews. 39: 46-58. http:/ / dx.doi.org/10.1016/j.arr.2016.10.005

30. Heilbronn LK, Ravussin E (2003) Calorie restriction and aging: review of the literature and implications for studies in humans. Am J Clin Nutr.78: 361-369

31. Rao KS (2003) Dietary calorie restriction, DNA repair and brain aging. Mol Cell Biochem. 253: 313-318

32. Masoro EJ (2000) Caloric restriction and aging: an update. Experimental Gerontology. 35: 299-305

33. Lu SP, Lin SJ (2010) Regulation of yeast sirtuins by NAD(+) metabolism and calorie restriction. Biochim Biophys Acta 1804: 1567-1575

34. Sinclair DA (2005) Toward a unified theory of caloric restriction and longevity regulation. Mech Ageing Dev 126: 987-1002

35. Smith DL, Nagy TR, Allison DB (2010) Calorie restriction: what recent results suggest for the future of ageing research. Eur J Clin Invest 40: $440-450$

36. Mattison JA, Colman RJ, Beasley TM, Allison DB, Kemnitz JW, i in. (2017) Caloric restriction improves health and survival of rhesus monkeys. Nat Commun 8: 14063

37. Colman RJ, Anderson RM, Johnson SC, Kastman EK, Kosmatka KJ, i in. (2009) Caloric restriction delays disease onset and mortality in rhesus monkeys. Science 325: 201-204

38. Austad SN (2012) Ageing: Mixed results for dieting monkeys. Nature 489: 210-211

39. Mattison JA, Roth GS, Beasley TM, Tilmont EM, Handy AM, i in. (2012) Impact of caloric restriction on health and survival in rhesus monkeys from the NIA study. Nature 489: 318-321

40. Lin SJ, Kaeberlein M, Andalis AA, Sturtz LA, Defossez PA, i in. (2002) Calorie restriction extends Saccharomyces cerevisiae lifespan by increasing respiration. Nature 418: 344-348

41. Barros MH, Bandy B, Tahara EB, Kowaltowski AJ (2004) Higher respiratory activity decreases mitochondrial reactive oxygen release and increases life span in Saccharomyces cerevisiae. J Biol Chem 279: 4988349888

42. Kaeberlein M, Hu D, Kerr EO, Tsuchiya M, Westman EA, i in. (2005) Increased life span due to calorie restriction in respiratory-deficient yeast. PLoS Genet 2(3):e33

43. Zuin A, Carmona M, Morales-Ivorra I, Gabrielli N, Vivancos AP, i in. (2010) Lifespan extension by calorie restriction relies on the Sty1 MAP kinase stress pathway. EMBO J 29: 981-991

44. Sharma PK, Agrawal V, Roy N (2011) Mitochondria-mediated hormetic response in life span extension of calorie-restricted Saccharomyces cerevisiae. Age (Dordr) 33: 143-154.

45. Tahara EB, Cunha FM, Basso TO, Della Bianca BE, Gombert AK, i in. (2013) Calorie restriction hysteretically primes aging Saccharomyces 
cerevisiae toward more effective oxidative metabolism. PLoS One 8: e56388

46. Huberts DH, González J, Lee SS, Litsios A, Hubmann G, i in. (2014) Calorie restriction does not elicit a robust extension of replicative lifespan in Sacharomyces cerevisiae. Proc Natl Acad Sci U S A 111: 1172711731

47. Maslanka R, Kwolek-Mirek M, Zadrag-Tecza R (2017) Consequences of calorie restriction and calorie excess for the physiological parameters of the yeast Saccharomyces cerevisiae cells. FEMS Yeast Res 17(8). doi: $10.1093 /$ femsyr/fox087

48. Maslanka R, Zadrag-Tecza R (2019) Less is more or more is less: Implications of glucose metabolism in the regulation of the reproductive potential and total lifespan of the Saccharomyces cerevisiae yeast. J Cell Physiol. 234:17622-17638

49. Weinberger M, Mesquita A, Caroll T, Marks L, Yang H, i in. (2010) Growth signaling promotes chronological aging in budding yeast by inducing superoxide anions that inhibit quiescence. Aging (Albany NY) 2: 709-726

50. Rolland F, Winderickx J, Thevelein JM (2002) Glucose-sensing and -signalling mechanisms in yeast. FEMS Yeast Res 2: 183-201

51. Maslanka R, Zadrag-Tecza R (2020) Reproductive Potential of Yeast Cells Depends on Overall Action of Interconnected Changes in Central Carbon Metabolism, Cellular Biosynthetic Capacity, and Proteostasis. International Journal of Molecular Sciences. 21: 7313

52. Tschen SI, Dhawan S, Gurlo T, Bhushan A (2009) Age-dependent decline in beta-cell proliferation restricts the capacity of beta-cell regeneration in mice. Diabetes 58: 1312-13120

53. Gunin AG, Kornilova NK, Petrov VV, Vasil'eva OV (2011) Age-related changes in the number and proliferation of fibroblasts in the human skin. Adv Gerontol 24: 43-47

54. Mortimer RK, Johnston JR (1959) Life span of individual yeast cells. Nature 183: 1751-1752

55. Smith J, Wright J, Schneider BL (2015) A budding yeast's perspective on aging: the shape I'm in. Exp Biol Med (Maywood) 240: 701-710

56. Zadrag-Tecza R, Kwolek-Mirek M, Bartosz G, Bilinski T (2009) Cell volume as a factor limiting the replicative lifespan of the yeast Saccharomyces cerevisiae. Biogerontology 10: 481-488

57. Biliński T, Zadrąg-Tęcza R, Bartosz G (2012) Hypertrophy hypothesis as an alternative explanation of the phenomenon of replicative aging of yeast. FEMS Yeast Res 12: 97-101

58. Bilinski T, Zadrag-Tecza R (2017) Yeast aging: Reproduction Strategies Determine the Longevity of Buding and Fission Yeasts, W: Shefferson
R, Owen J (red), The Evolution of Senescence in the Tree of Life, Cambridge University Press

59. Zadrag-Tecza R, Kwolek-Mirek M, Alabrudzińska M, Skoneczna A (2018) Cell Size Influences the Reproductive Potential and Total Lifespan of the. Oxid Med Cell Longev 2018: 1898421

60. Yang J, Dungrawala H, Hua H, Manukyan A, Abraham L, i in. (2011) Cell size and growth rate are major determinants of replicative lifespan. Cell Cycle 10: 144-155

61. Nidelet T, Brial P, Camarasa C, Dequin S (2016) Diversity of flux distribution in central carbon metabolism of $S$. cerevisiae strains from diverse environments. Microb Cell Fact 15: 58

62. Busti S, Mapelli V, Tripodi F, Sanvito R, Magni F, i in. (2016) Respiratory metabolism and calorie restriction relieve persistent endoplasmic reticulum stress induced by calcium shortage in yeast. Sci Rep 6: 27942

63. Rinnerthaler M, Büttner S, Laun P, Heeren G, Felder TK, i in. (2012) Yno1p/Aim14p, a NADPH-oxidase ortholog, controls extramitochondrial reactive oxygen species generation, apoptosis, and actin cable formation in yeast. Proc Natl Acad Sci U S A 109: 8658-8663

64. Angello JC, Pendergrass WR, Norwood TH, Prothero J (1987) Proliferative potential of human fibroblasts: an inverse dependence on cell size. J Cell Physiol 132: 125-130

65. Anzi S, Stolovich-Rain M, Klochendler A, Fridlich O, Helman A, i in. (2018) Postnatal Exocrine Pancreas Growth by Cellular Hypertrophy Correlates with a Shorter Lifespan in Mammals. Dev Cell 45: 726-737. e3

66. Verduyn C, Postma E, Scheffers WA, van Dijken JP (1990) Physiology of Saccharomyces cerevisiae in anaerobic glucose-limited chemostat cultures. J Gen Microbiol 136: 395-403

67. Martorana F, Gaglio D, Bianco MR, Aprea F, Virtuoso A, i in. (2018) Differentiation by nerve growth factor (NGF) involves mechanisms of crosstalk between energy homeostasis and mitochondrial remodeling. Cell Death Dis 9: 391

68. Tamaki H, Yun CW, Mizutani T, Tsuzuki T, Takagi Y, i in. (2005) Glucose-dependent cell size is regulated by a $\mathrm{G}$ protein-coupled receptor system in yeast Saccharomyces cerevisiae. Genes Cells 10: 193-206

69. Youk H, van Oudenaarden A (2009) Growth landscape formed by perception and import of glucose in yeast. Nature 462: 875-879

70. Zadrag-Tecza R, Molon M, Mamczur J, Bilinski T (2013) Dependence of the yeast Saccharomyces cerevisiae post-reproductive lifespan on the reproductive potential. Acta Biochim Pol 60: 111-115 


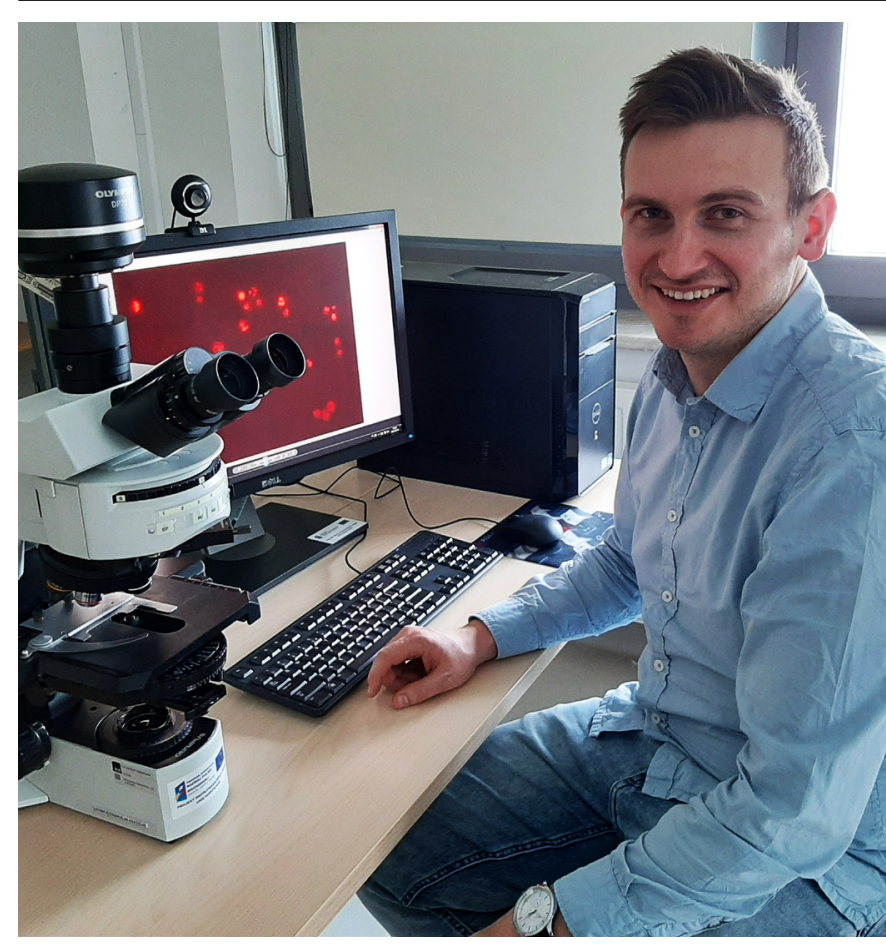

\section{Dr Roman Maślanka}

Jestem absolwentem biologii oraz technologii żywności i żywienia człowieka Uniwersytetu Rzeszowskiego. Obecnie pracuję w Instytucie Biologii i Biotechnologii, w Zakładzie Biochemii i Biologii Komórki. Wspólnie z pracownikami zespołu badawczego kierowanego przez dr hab. Renatę Zadrąg-Tęcza, prof. UR poszukuję odpowiedzi na pytanie w jaki sposób regulowany jest potencjał reprodukcyjny komórek. Realizowane przeze mnie badania dotyczą głównie zmian wywołanych różną dostępnością składników niezbędnych do prawidłowego funkcjonowania komórki. Szczególnie istotne są dla mnie kwestie związane z restrykcją kaloryczną, okresowym głodzeniem, nadmiarem kalorii oraz metabolizmem glukozy. Na modelu badawczym, którym na chwilę obecną są dla mnie komórki drożdży Saccharomyces cervisiae analizuję $\mathrm{w}$ jaki sposób ograniczenie i nadmiar kluczowego substratu jakim dla komórki jest glukoza moduluje stan fizjologiczny, architekturę wewnątrzkomórkową, procesy biosyntetyczne i degradacyjne komórki oraz jaki ma to wpływ na ich zdolności proliferacyjne. Do moich zainteresowań należą także kwestie związane z toksycznością akrylamidu oraz stanem redoks komórki. Poza pracą naukową staram się również angażować $\mathrm{w}$ działania popularyzujące naukę pełniąc m.in. funkcję Przewodniczącego Zespołu ds. Promocji Instytutu Biologii i Biotechnologii UR oraz Koordynatora akcji Nocy Biologów na Uniwersytecie Rzeszowskim. Prywatnie idealista i niepoprawny optymista, pasjonat thrillerów medycznych, muzyki alternatywnej, wycieczek rowerowych i eksperymentowania w kuchni, a ze względu na pochodzenie (rodowity mieszkaniec terenów doliny Popradu) miłośnik wycieczek górskich, przebywania w lesie i grzybobrania.

\title{
Multifaceted role of glucose and its metabolism in the regulation of physiological parameters and reproductive potential of the cells on the example of research using the yeast Saccharomyces cerevisiae Roman Maślanka ${ }^{\varpi}$, Renata Zadrąg-Tęcza
}

Department of Biochemistry and Cell Biology, College of Natural Sciences, Rzeszow University, Rzeszow, Poland

$\bowtie$ Author for corrspondence: rmaslanka@ur.edu.pl

Keywords: glucose, calorie restriction, calorie excess, cell size, biosynthetic capabilities, cell reproductive potential, yeast Saccharomyces cerevisiae

\begin{abstract}
Glucose is not only the primary source of energy, but also a compound which plays an important role in the metabolism and maintenance of the proper physiological state of the cell. This is particularly pronounced in the case of yeasts, in which the influence of glucose on the physiological state of the cell is directly manifested. Among other by obtaining energy through fermentation or aerobic respiration depending on the availability of glucose. Glucose-dependent modulation of intracellular metabolic pathways influence on the reproductive potential and lifespan of the cells, what links glucose with calorie restriction studies. At the same time, there is a noticeable lack of data concerning the calorie excess and its consequences at the cellular level. Using the yeast Saccharomyces cerevisiae cells as a research model, a significant relationship between glucose concentration, biosynthetic efficiency, reproductive potential and total lifespan of yeast cells was found. High glucose concentrations, corresponding to the calorie excess conditions, lead to an increase in the level of reactive oxygen species, an increase in cell size and cell biomass, but at the same time, it reduces the reproductive potential and shortens the total lifespan of the yeast cell. The negative impact of glucose excess on the physiological state of the cell as well as the complexity and interrelationships of intracellular metabolic pathways suggest that the issue of glucose metabolism need further investigations.
\end{abstract}

